\title{
The DNA Repair-Associated Protein Gadd45 $\gamma$ Regulates the Temporal Coding of Immediate Early Gene Expression within the Prelimbic Prefrontal Cortex and Is Required for the Consolidation of Associative Fear Memory
}

\author{
Xiang Li, ${ }^{\star}$ Paul R. Marshall, ${ }^{\star}$ Laura J. Leighton, Esmi L. Zajaczkowski, Ziqi Wang, Sachithrani U. Madugalle, Jiayu Yin, \\ (DTimothy W. Bredy, and Wei Wei \\ Cognitive Neuroepigenetics Laboratory, Queensland Brain Institute, The University of Queensland, St. Lucia, Queensland 4072, Australia
}

\begin{abstract}
We have identified a member of the growth arrest and DNA damage (Gadd45) protein family, Gadd45 $\gamma$, which is known to be critically involved in DNA repair, as a key player in the regulation of immediate early gene (IEG) expression underlying the consolidation of associative fear memory in adult male C57BL/6 mice. Gadd $45 \gamma$ temporally influences learning-induced IEG expression in the prelimbic prefrontal cortex (PLPFC) through its interaction with DNA double-strand break (DSB)-mediated changes in DNA methylation. Our findings suggest a two-hit model of experience-dependent IEG activity and learning that comprises (1) a first wave of IEG expression governed by DSBs and followed by a rapid increase in DNA methylation, and (2) a second wave of IEG expression associated with the recruitment of Gadd $45 \gamma$ and active DNA demethylation at the same site, which is necessary for memory consolidation.
\end{abstract}

Key words: DNA double-strand break; DNA methylation; DNA repair; immediate early gene; memory consolidation; neuroepigenetic

\section{Significance Statement}

How does the pattern of immediate early gene transcription in the brain relate to the storage and accession of information, and what controls these patterns? This paper explores how Gadd $45 \gamma$, a gene that is known to be involved with DNA modification and repair, regulates the temporal coding of IEGs underlying associative learning and memory. We reveal that, during fear learning, Gadd $45 \gamma$ serves to act as a coordinator of IEG expression and subsequent memory consolidation by directing temporally specific changes in active DNA demethylation at the promoter of plasticity-related IEGs.

\section{Introduction}

Memory consolidation requires learning-induced gene expression, protein synthesis, and changes in synaptic plasticity (Izquierdo and McGaugh, 2000; Kandel, 2001). For decades, models of cued and contextual fear conditioning have been used to advance

Received Aug. 7, 2018; revised Nov. 11, 2018; accepted Dec. 4, 2018.

Author contributions: X.L. and P.R.M. wrote the first draft of the paper; L.J.L., T.B., and W.W. edited the paper; X.L., P.R.M., T.W.B., and W.W. designed research; X.L., P.R.M., L.J.L., E.L.Z., Z.W., S.U.M., J.Y., and W.W. performed research; X.L., P.R.M., T.W.B., and W.W. analyzed data; W.W. wrote the paper.

This work was supported by Grants from the NIH (5R01MH105398-TWB) and the NHMRC (APP1033127-TWB), and by postgraduate scholarships from the University of Queensland and the ANZ Trustees Queensland for Medical Research and University of Queensland development fellowship to X.L., from NSERC and the University of Queensland to P.R.M., and from the Westpac Bicentennial Foundation and the University of Queensland to L.J.L. We thank Rowan Tweedale for helpful editing of the paper.

The authors declare no competing financial interests.

*X.L. and P.R.M. contributed equally to this work.

Correspondence should be addressed to Wei Wei at w.wei@uq.edu.au or Timothy W. Bredy at t.bredy@uq.edu.au.

https://doi.org/10.1523/JNEUROSCI.2024-18.2018

Copyright $\odot 2019$ the authors $\quad 0270-6474 / 19 / 390970-14 \$ 15.00 / 0$ the understanding of the cellular, molecular, and circuit-level mechanisms of learning and memory. Although the amygdala and hippocampus have historically been the primary focus of studies on fear-related learning, it is becoming evident that the prefrontal cortex (PFC) is also involved in the initial encoding of fear memories, with the dorsomedial or prelimbic region of the PFC playing a particularly important role (Giustino and Maren, 2015; Dejean et al., 2016; Widagdo et al., 2016; Klavir et al., 2017; Rizzo et al., 2017; Santos et al., 2017). With respect to genomic responses to learning, several members of a particularly unique class of inducible genes known as the immediate early genes are rapidly and transiently expressed in response to neural activity, and are thought to be important for information processing in the brain because of the tight temporal relationship between their expression and learning. Specifically, activity-regulated cytoskeleton-associated protein (Arc), fos proto-oncogene (c-Fos), and neuronal PAS domain protein 4 (Npas4) have all been shown to be critically involved in memory formation (Minatohara et al., 2016; Sun and Lin, 2016; Gallo et al., 2018). However, a detailed 
understanding of the molecular mechanisms by which these IEGs are regulated during learning and the formation of memory remains to be developed.

It has become increasingly evident that there is an important epigenetic layer of regulatory control over gene expression and memory, which includes DNA modification (Baker-Andresen et al., 2013). DNA methylation and active DNA demethylation are directly involved in gene expression underlying memory formation (Li et al., 2014), and several recent studies have extended these findings to include IEGs. For example, RNA-directed changes in DNA methylation regulate c-Fos expression by directing DNA methyltransferase (DNMT) activity to the c-Fos promoter (Savell et al., 2016). DNA hydroxymethylation regulates both c-Fos and Arc expression in the hippocampus (Rudenko et al., 2013), and chronic drug exposure increases DNA methylation at the c-Fos and Arc promoters, which has a profound effect on learning and memory (Massart et al., 2015; Wright et al., 2015). Several active DNA demethylation pathways have been proposed, and each has been shown to be involved in regulating gene expression related to plasticity and memory (Li et al., 2013, 2014; Kaas et al., 2013; Rudenko et al., 2013; Ratnu et al., 2014). Perhaps most direct pathway involves independent members of the Gadd 45 family of DNA repair proteins $(\alpha, \beta$, and $\gamma)$, where each has been shown to form a complex with DNA repair enzymes to guide the removal of 5-mC by either base or nucleotide excision repair (Barreto et al., 2007; Rai et al., 2008; Ma et al., 2009).

Early reports indicated that in sensory and motor neurons, Gadd $45 \alpha$ is induced by nerve injury (Befort et al., 2003), whereas Gadd $45 \beta$ was found to be activity-dependent and involved in neurogenesis (Ma et al., 2009). With respect to experiencedependent plasticity in the adult brain, Gadd $45 \beta$ has also been shown to influence memory formation, although reports differ with regards to whether its knockdown leads to enhancement (Sultan et al., 2012) or impairment of contextual fear memory (Leach et al., 2012). Although fear-related learning led to a significant increase in Gadd $45 \gamma$ mRNA expression in the hippocampus and amygdala (Sultan et al., 2012), and the expression of Gadd45 $\beta$, Gadd45 $\gamma$, and Arc and a relationship with DNA methylation in a mouse model of depression has been reported (Grassi et al., 2017), whether any members of the Gadd 45 family of proteins contribute to memory formation through direct effects on IEG expression has yet to be determined.

\section{Materials and Methods}

Mice. Nine- to 11-week-old C57BL/6J (Animal Resource Centre) male mice were housed four per cage, maintained on a $12 \mathrm{~h}$ light/dark schedule, and allowed ad libitum access to food and water. All testing was conducted during the light phase in red-light-illuminated testing rooms following protocols approved by the Animal Ethics Committee of the University of Queensland.

Culture and usage of primary mouse cortical neurons. Primary mouse cortical neuron cultures were prepared and maintained as previously described (Lin et al., 2011). To knock down expression of genes of interest, cultured neurons at 2-3 din vitro were exposed to lentivirus, followed by replacement of the culture medium. To investigate activity-dependent gene regulation, cultured neurons were depolarized by the addition of 20 $\mathrm{mM} \mathrm{KCl}$ to the culture medium after 7-10 d. Cells were collected for molecular analysis immediately at the end of the $\mathrm{KCl}$ exposure time.

Culture of Neuro2A, HT-22, and HEK293T cells. Neuro2A (N2A) cells were maintained in medium consisting of 50\% DMEM, high glucose (Invitrogen), and 50\% Opti-MEM (Invitrogen) supplemented with 5\% fetal bovine serum and 1\% Pen/Strep. HT-22 and HEK293T cells were maintained in DMEM, high glucose (Invitrogen) supplemented with $10 \%$ fetal bovine serum and $1 \%$ Pen/Strep.
RNA isolation and reverse transcription. To extract RNA, cells were lysed with NucleoZOL (Macherey-Nagel) directly in the culture dish and RNA was isolated following the manufacturer's instructions. Reverse transcription was performed using the QuantiTect kit (Qiagen) using the provided RT Primer Mix and following the manufacturer's instructions.

Quantitative PCR for gene expression. Quantitative PCRs were prepared in duplicate, in a $10 \mu \mathrm{l}$ reaction volume, using $2 \times$ SYBR master mix (Qiagen), $500 \mu \mathrm{M}$ of each primer, and $1 \mu \mathrm{l}$ per reaction of a cDNA sample (the cDNA dilution factor varied according to target abundance). Reactions were run on the Rotor-Gene Q platform and results were analyzed using the $\delta \delta \mathrm{cT}$ method, normalized to the reference gene $P G K$ (phosphoglycerate kinase). qPCR primers used including: qGadd $45 \alpha$ F: CCGAAAGGATGGACACGGTG; qGadd $45 \alpha$ R: TTATCGGGGTC TACGTTGAGC; qGadd $45 \beta$ F: CACCCTGATCCAGTCGTTCT; qGadd $45 \beta$ R: TTGCCTCTGCTCTCTTCACA; qGadd $45 \gamma$ F: GGGAAAG CACTGCACGAACT; qGadd45 $\gamma$ R: AGCACGCAAAAGGTCACATTG; qCyr61 F: CTGCGCTAAACAACTCAACGA; qCyr61 R: GCAGATCCCTTTCAGAGCGG; qc-Fos F: GAACGGAATAAGATGGCTGC; qcFos R: TTGATCTGTCTCCGCTTGG; qNpas4 F: CTGCATCTACACT CGCAAGG; qNpas4 R: GCCACAATGTCTTCAAGCTCT; qArc F: AAGTGCCGAGCTGAGATGC; qArc R: CGACCTGTGCAACCCT TTC; qPGK F: TGCACGCTTCAAAAGCGCACG; qPGK R: AAGTCCA CCCTCATCACGACCC. Data were analyzed using Student's $t$ test or one-way ANOVA where appropriate.

DNA extraction. PLPFC tissue from naive and trained mice was dissociated by dounce homogenization in $500 \mu \mathrm{l}$ PBS. Preparation of DNA was performed using the DNeasy Blood and Tissue Kit (Qiagen), according to the manufacturer's instructions.

Protein extract and Western blot. Total protein was extracted using NP40 lysis buffer (ThermoFisher) following the manufacturer's protocol. Protein concentration was determined using the Qubit protein assay (Invitrogen). For Western blot, samples were prepared on ice (to final volume of $20 \mu \mathrm{l}$ ), and then vortexed and denatured for $10 \mathrm{~min}$ at $90^{\circ} \mathrm{C}$. PAGE was performed and proteins transferred onto nitrocellulose membrane (Bio-Rad). The membrane was blocked using Li-Cor blocking buffer for $1 \mathrm{~h}$ at room temperature, washed with Tris-buffered saline containing 1\% Tween 20 (TBS-T) three times for 5 min each, then incubated with different antibodies (Gadd $45 \alpha$ : Cell Signaling Technology, catalog \#4632; Gadd45 $\beta$ : Abcam, catalog \#ab105060; Gadd45 $\gamma$ : Abcam, catalog \#ab105060; Beta-actin: Cell Signaling Technology, catalog \#3700) diluted in Li-Cor blocking buffer overnight at $4^{\circ} \mathrm{C}$. Membranes were then washed three times with TBS-T, incubated for $1 \mathrm{~h}$ with anti-mouse secondary antibody (1:15,000; Li-Cor) and anti-rabbit secondary antibody (1:15000; Li-Cor) diluted in blocking buffer, and washed three times with TBST for 10-20 min. Optical density readings of the membrane were taken using the Li-Cor FX system.

Methylated DNA immunoprecipitation. Methylated DNA immunoprecipitation (MeDIP) was performed using the Active Motif kit (catalog \#55009). In brief, DNA was fragmented with the Covaris M220, and then heat denatured. Following this, fragments containing at least one 5-mC were captured with a 5-mC antibody bound to protein G Dynabeads (Invitrogen). The beads were then washed and DNA fragments with 5-mC were eluted for quantitative PCR.

Chromatin immunoprecipitation. Chromatin immunoprecipitation (ChIP) was performed using the Invitrogen ChIP kit, with a modified protocol. Lysate from cells or tissue was fixed with $1 \%$ formaldehyde and cross-linked cell lysates were sheared in 1\% SDS lysis buffer using the Covaris M220, generating chromatin fragments with an average length of $300 \mathrm{bp}$. Various antibodies (Gadd $45 \alpha$ : Cell Signaling Technology, cata$\log$ \#4632; Gadd45 $\beta$ : Abcam, catalog \#ab105060; Gadd45 $\gamma$ : Santa Cruz Biotechnology, catalog \#sc-393261; $\gamma$ H2a.X: Abcam, catalog \#ab2893; topoisomerase 2 beta (Topo II $\beta$ ): Santa Cruz Biotechnology, catalog \#sc-365071; DNMT3a: Active Motif, catalog \#39206; rabbit IgG: Millipore, catalog \#12-370; mouse IgG: Millipore, catalog \#12-371) were used to perform immunoprecipitation; additionally, each antibody was paired with an equivalent quantity of IgG as a negative control for validation purposes. Antibodies were incubated with the sheared lysates overnight at $4^{\circ} \mathrm{C}$ with gentle agitation, and protein-DNA-antibody complexes were then precipitated with Protein $\mathrm{G}$ Dynabeads for $1 \mathrm{~h}$ at $4^{\circ} \mathrm{C}$, followed by 
three washes in low-salt buffer, and three washes in high-salt buffer. The precipitated protein-DNA complexes were eluted from the captured antibody with $1 \%$ SDS and $0.1 \mathrm{M} \mathrm{NaHCO}_{3}$, then incubated overnight at $65^{\circ} \mathrm{C}$ in $200 \mathrm{~mm} \mathrm{NaCl}$ to reverse formaldehyde cross-linkages. Samples were then digested with Proteinase K, and the DNA extracted with phenol-chloroform and purified by ethanol precipitation. DNA was used for quantitative PCR using primers specific to the proximal promoter regions of IEGs (Chip-Cyr61 F: GGTCAAGTGGAGAAGGGTGA; ChipCyr61 R: GCACCTCGA GAGAAGGACAC; Chip-Fos F: GAAAGCCTGGGGCGTAGAGT; Chip-Fos R: CCTCAGCTGGCGCCTTTAT; Chip-Npas4 F: GATCGTGGGAGAGGTTCAAA; Chip-Npas4 R: TCACAACTGGGGGTCTTTTC; Chip-Arc F: CCTCAGCTGCCTTTG GTTAG; Chip-Arc R: GAAAAAGCCTTGCCTGAGTG).

Quantitative PCR for ChIP and MeDIP samples. Quantitative PCRs were prepared in duplicate, using $2 \times$ SYBR master mix (Qiagen), $500 \mu \mathrm{M}$ of each primer, and $1 \mu \mathrm{l}$ of template DNA purified as described previously after immunoprecipitation. Reactions were run on the Rotor-Gene $Q$ platform and results were analyzed using the $\delta \delta \mathrm{cT}$ method normalized to input samples.

Lentivirus construction and packaging. Lentivirus was packaged according to our previously published protocol (Lin et al., 2011). Briefly, HEK293T cells were grown to $70-80 \%$ confluence in triple-layer flasks. Cells were transfected with the plasmids pMDG, pRSV-rev, pMDLg/ pRRE, and the transfer vector (gene-specific shRNA cloned into FG12) using Lipofectamine 3000 reagent according to the manufacturer's instructions. Transfected cells were cultured for $48 \mathrm{~h}$, then the culture media was collected, clarified, filtered, and lentivirus particles were concentrated by ultracentrifugation. Concentrated viral pellets were resuspended in PBS and snap-frozen. Five lentiviruses were produced: one carrying a control shRNA with no specificity to any known mouse transcript, and one targeting each of Gadd $45 \alpha$, Gadd $45 \beta$, Gadd $45 \gamma$ and Cyr61 (Gadd $45 \alpha$ shRNA: CCACATTCATCACAATGGA; Gadd $45 \beta$ shRNA: ACGAACTGTCATACAGATT; Gadd $45 \gamma$ shRNA: AGATCCATT TCACGTTGAT; Cyr61 shRNA: TCCAGCCCAACTGTAAACA; Universal control shRNA: GCGCGATAGCGCTAATAAT).

Titration of virus. Four $\times 10^{5} 293$ T cells/well of a 6 well plate were plated the day before titration of virus. On the following day, the number of cells in each well were estimated by counting. Then, four dilutions of each virus were prepared, corresponding to $0.5,1,2$, and $5 \mu \mathrm{l}$ per well, and added to the HEK cells which were then incubated for $2-3 \mathrm{~d}$. The percentage of cells expressing e-GFP was used to calculate the virus titer by using the following formula: (\% GFP-positive cells) $\times(\mu$ l of virus added to well $) /$ (number of cells in well before infection $)=$ infectious units $(\mathrm{IU}) / \mathrm{ml} \times 10^{3}=\mathrm{IU} / \mathrm{ml}$. The titers of shRNA lentivirus for Gadd $45 \alpha$, Gadd $45 \beta$, Gadd $45 \gamma$, Cyr61, and control are $\sim 1.5 \times 10^{8} \mathrm{IU} /$ $\mathrm{ml}, 1.3 \times 10^{8} \mathrm{IU} / \mathrm{ml}, 1 \times 10^{8} \mathrm{IU} / \mathrm{ml}, 2 \times 10^{8} \mathrm{IU} / \mathrm{ml}$, and $1.4 \times 10^{8}$ $\mathrm{IU} / \mathrm{ml}$, separately.

Stereotaxic surgery. Double cannulae (Plastics One) were implanted in the anterior-posterior plane, along the midline, into the PLPFC. The cannula placements were centered at +1.80 in the anterior-posterior plane, and $-2.20 \mathrm{~mm}$ in the dorsal-ventral plane, relative to bregma. Following surgery, animals were single-housed and given at least 1 week to recover. After the recovery period, mice were infused with lentivirus through both cannulae; $0.5 \mu \mathrm{l}$ was infused through each cannula on 2 consecutive days, for a total delivered volume of $2.0 \mu \mathrm{l}$ per animal. Following virus infusion, a 1 week waiting period was observed to ensure stable expression of the viral construct. For antibody injection, saline or Gadd $45 \gamma$ antibody was premixed with $0.1 \%$ Triton $\times 100$ and $1 \mu \mathrm{l}$ was infused into each side $3 \mathrm{~h}$ after cued fear conditioning. Etoposide (SigmaAldrich, catalog \#E1383) was dissolved in 1\% DMSO at two different concentrations ( $1 \mathrm{ng}$ or $0.1 \mu \mathrm{g} / \mu \mathrm{l}$ ) and mice were bilaterally infused with $0.5 \mu \mathrm{l}$ of etoposide or $1 \%$ DMSO as control.

DsiRNA design and injection. Three separate dicer-substrate siRNAs (DsiRNAs) against Cyr61 were designed using an online design tool provided by Integrated DNA Technologies (https://sg.idtdna.com/site/ order/designtool/index/DSIRNA_CUSTOM). DsiRNAs were tested in HT-22 cells and compared with a universal negative control that does not recognize any sequences in human, mouse, or rat transcriptomes. After determining which DsiRNA-Cyr61 had the maximum knockdown effi- ciency, we reordered DsiRNA with 2'-O-methylated modified nucleotides to provide further stability and avoid triggering an innate immune response which can be harmful to the animal (DsiRNA-Cyr61 sense: mGmArUmGrUmUrUrUrCrCrAmArGmArAmUrGmUrCrArUrGrAmUG; DsiRNA-Cyr61 antisense: rCrAmUrCrArUrGrAmCrAmUrUmCrUrUrGrGrArArArArCmArUmCmUmC; DsiRNA-cont sense: $\mathrm{mCm}$ GrUmUrAmArUrCrGrCrGmUrAmUrAmArUmArCrGrCrGrUmAT; DsiRNA-cont antisense: rArUmArCrGrCrGrUmArUmUrAmUrAr CrGrCrGr ArUrUrAmArCmGmAmC). Two concentrations of DsiRNA-Cyr61 were tested $(100 \mathrm{~nm} / \mu \mathrm{l}$ or $10 \mathrm{~nm} / \mu \mathrm{l})$ by bilateral infusion of $1 \mu \mathrm{l}$ into the PLPFC.

Fear conditioning and recall tests. Mice underwent cued fear conditioning in operant chambers (Coulbourn Instruments), which have two transparent walls and two stainless steel walls, with a square shape and steel grid floor. The training context was scented using a dilute solution of lemon essence. The training protocol consisted of three pairings of a $120 \mathrm{~s}, 80 \mathrm{~dB}$, pure tone stimulus (CS) with a $1 \mathrm{~s}, 0.7 \mathrm{~mA}$, foot shock (US), separated by an empty $10 \mathrm{~s}$ trace interval. The pretrial interval, intertrial interval, and post-trial interval were all $120 \mathrm{~s}$ long. Movement was captured by cameras in the boxes and processed with the software FreezeFrame 4 to determine the percentage-based freezing score, with "freezing" defined as $1 \mathrm{~s}$ or more of immobility. The context-only control mice were placed in the same context for $16 \mathrm{~min}$ (the same duration as the training protocol) without the cue sound or the shock. Twenty-four hours after training, mice were returned to the context for recall tests. Following a $2 \mathrm{~min}$ acclimation period (to reduce context generalization), freezing was assessed during two $120 \mathrm{~s}$ CS presentations (with $120 \mathrm{~s}$ intertrial interval). Memory was inferred by the observing percentage of time spent freezing during the recall tests.

Open-field test. Following completion of other behavioral testing, mice were tested in open fields to check for off-target behavioral effects that could cause a change in freezing score unrelated to memory (specifically, increased generalized anxiety or reduced spontaneous locomotion). Open-field tests were conducted in a sound-attenuated room dimly illuminated with white lighting ( $60 \pm 3 \mathrm{lux})$. Mice were placed into the center of a white plastic open field $(30 \times 30 \times 30 \mathrm{~cm})$ and recorded with an overhead camera for $20 \mathrm{~min}$. Videos were analyzed using Noldus EthoVision 11 to determine the distance traveled, and the number of entries into and cumulative time spent in the center of the arena (defined as a $15 \times 15 \mathrm{~cm}$ square concentric with the base of the arena).

Statistical analyses. All statistics were performed using Prism7. Following analysis of descriptive statistics, two-tailed unpaired Student's $t$ test was used for direct comparisons between fear and contextual control groups at each time point. One-way or two-way ANOVA was chosen for multiple comparisons when whichever was appropriate. All multiplecomparison tests were adjusted using a Sidak correction. Error bars represent SEM. Significant differences were accepted at $p<0.05$.

\section{Results}

Learning-induced Gadd45y expression in the PLPFC is required for the formation of cued fear memory

To establish which members of the Gadd 45 family are associated with learning, we first examined Gadd45 $\alpha$, Gadd45 $\beta$, and Gadd45 $\gamma$ mRNA expression in stimulated cortical neurons, in vitro, and in the PLPFC in response to cued fear learning in adult mice. In vitro, neural activation led to a significant increase in Gadd $45 \beta$ and Gadd45 $\gamma$, but not Gadd $45 \alpha$, mRNA transcripts (data not shown). However, contrary to previous findings in the hippocampus and amygdala (Leach et al., 2012; Sultan et al., 2012), we found that only Gadd45 $\gamma$ mRNA exhibited a significant increase in the PLPFC in response to cued fear conditioning (Fig. $1 A-C ; t_{(6)}=2.63$, CTX 3 h vs FC $3 \mathrm{~h}, p=0.0392, t_{(6)}=6.46$, CTX $5 \mathrm{~h}$ vs FC $5 \mathrm{~h}, p=0.007$, and $t_{(6)}=3.87$, CTX $12 \mathrm{~h}$ vs FC $12 \mathrm{~h}, p=$ 0.029 , unpaired $t$ test). Given that the level of mRNA expression does not necessarily reflect the functional relevance of the transcript (Nainar et al., 2016) and considering previous findings of a role for Gadd $45 \beta$ in regulating contextual fear memory, we next 
A

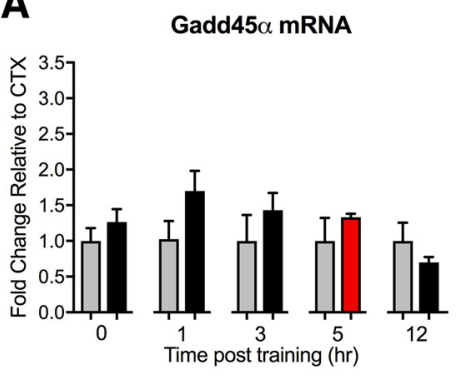

B

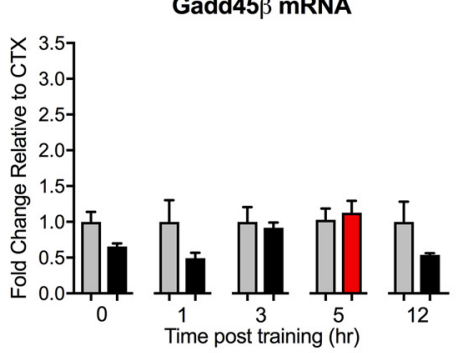

C

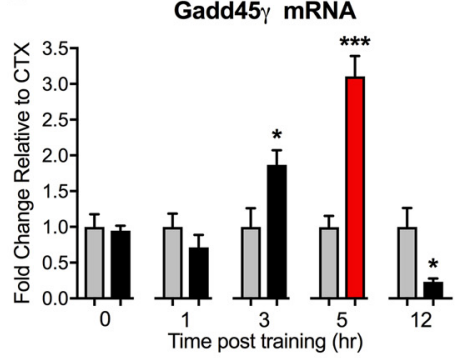

D

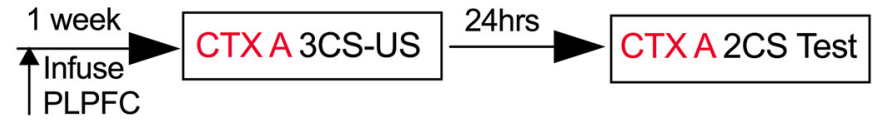

E

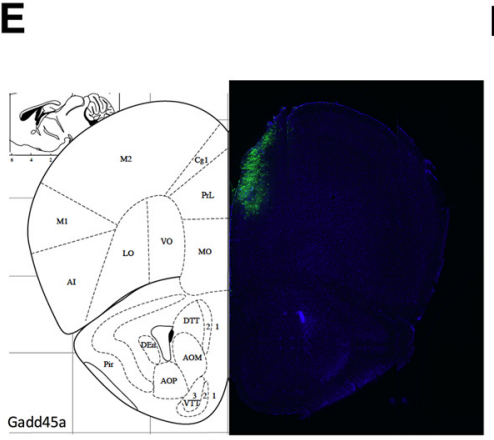

H

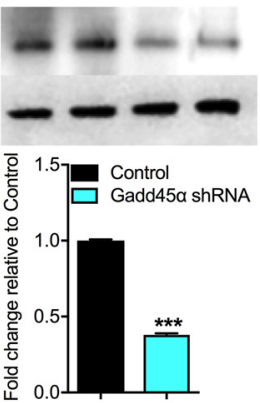

$\mathbf{F}$

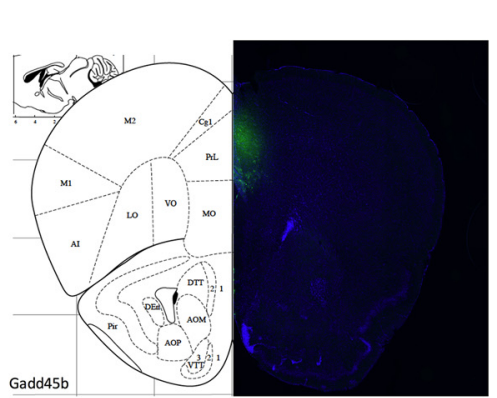

I

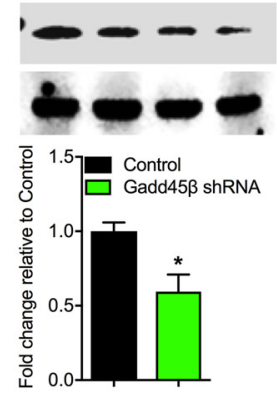

G

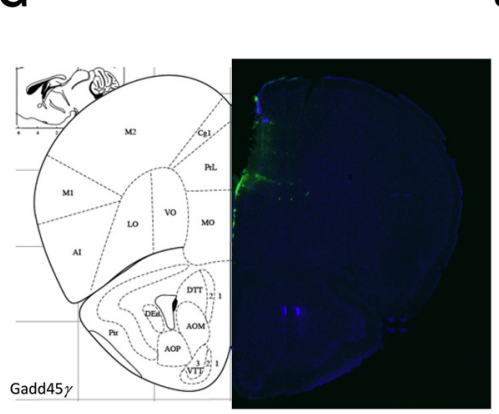

J

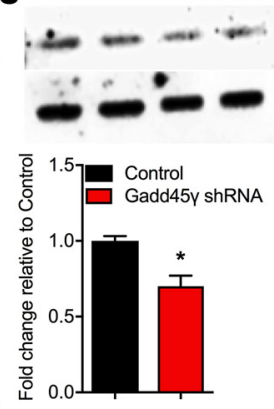

K

\section{Gadd45 $\alpha$ shRNA fear memory}

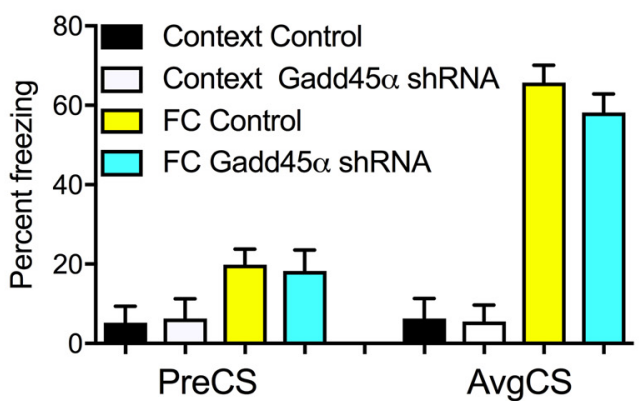

$\mathbf{L}$

\section{Gadd45 $\beta$ shRNA fear memory}

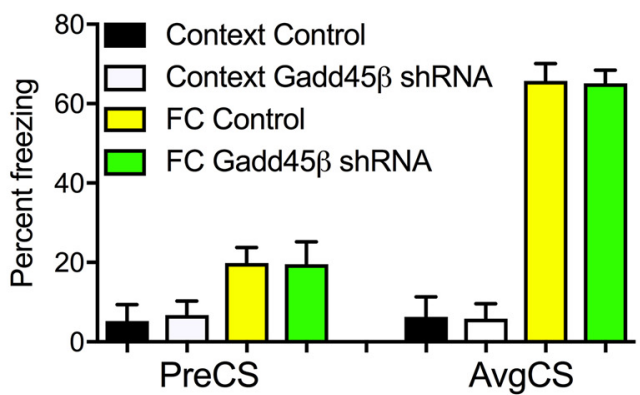

M

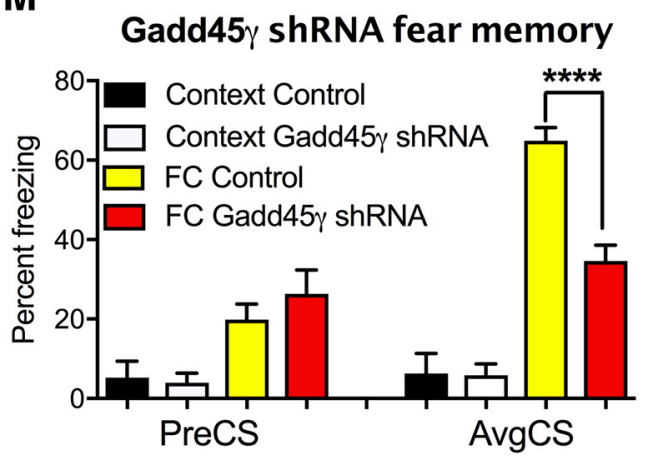

Figure 1. Gadd45 $\gamma$ expression is activity-dependent and necessary for cued fear learning in the PLPFC. $\boldsymbol{A}-\boldsymbol{C}$, Fold-change for fear conditioned animals which is calculated relative to each group's own context control at that time point. $\boldsymbol{A}$, Following cued fear conditioning there was no significant change in Gadd45 $\alpha$ or $(\boldsymbol{B})$ Gadd45 $\beta$ mRNA levels. $\boldsymbol{C}$, There was a significant increase in Gadd45 $\gamma$ 3 and $5 \mathrm{~h}$ post-conditioning and decrease at $12 \mathrm{~h}$ time point. $\boldsymbol{D}$, Time course of behavioral training and shRNA infusion. $\boldsymbol{E}-\boldsymbol{G}$, Representative images show the location of infused lentivirus expressing shRNA knockdown effect at $\sim 55,50$, and $40 \%$ for $(\boldsymbol{H}) \mathrm{Gadd} 45 \alpha,(\boldsymbol{I}) \mathrm{Gadd} 45 \beta$, and $(\boldsymbol{J}) \mathrm{Gadd} 45 \gamma$, separately, at the protein level. There were no significant differences in percentage freezing during the fear test for animals infused with either Gadd45 $\alpha$ shRNA $(\boldsymbol{K})$ or Gadd45 $\beta$ shRNA lenti-virus $(\boldsymbol{L})$ compared with the control, which has no specificity to any known (Figure legend continues.) 
A

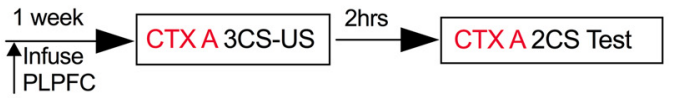

B Fear acquisition

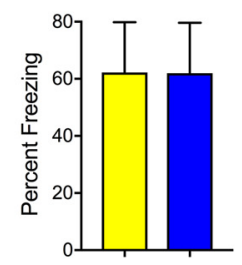

C

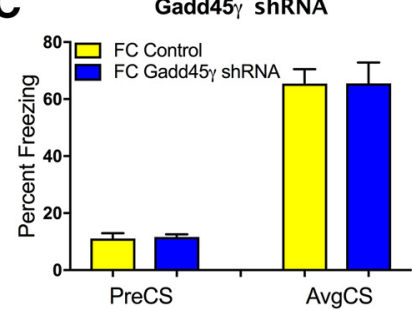

G

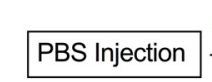

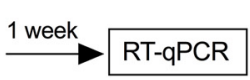

I

J
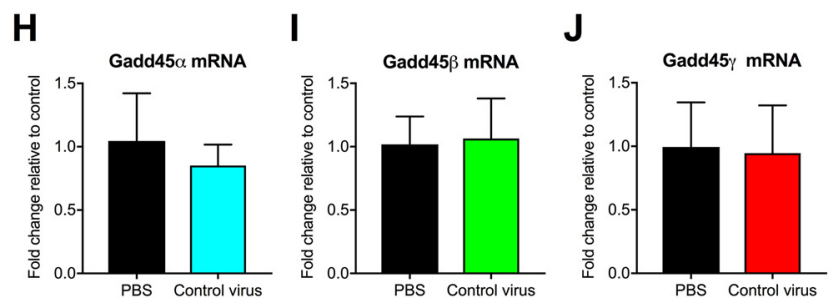

D

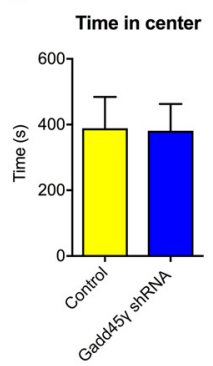

K

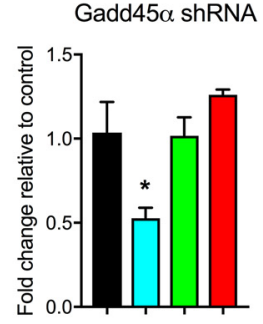

E

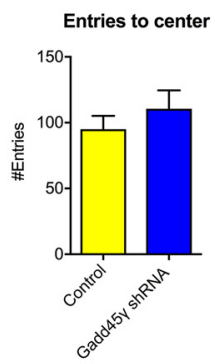

L

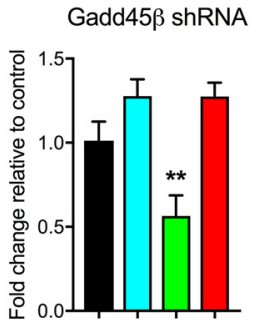

F

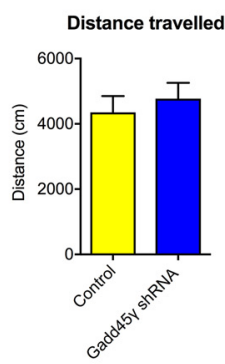

M Gadd45y shRNA

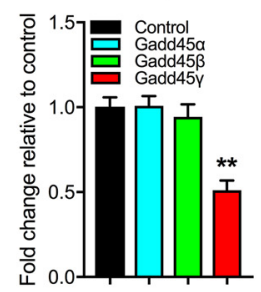

Figure 2. Control experiments showing no nonspecific effect of shRNA lentivirus injection on behavior and gene expression. $A$, Time course of behavioral training. Gadd45 $\gamma$ knockdown had no effect on fear acquisition $(\boldsymbol{B})$ and short memory when tested $2 \mathrm{~h}$ post-training $(\boldsymbol{C} ; N=8$ per group). Open-field test results show that there is no effect of on generalized anxiety as measured by time spent in the center of the open field $(\boldsymbol{D})$ or the number of entries to the center zone $(\boldsymbol{E})$; likewise, there is no effect on locomotion $(\boldsymbol{F} ; N=7-8$ per group). $\mathbf{G}$, Time course of behavioral training. Compared with PBS injection, lenti-viral transduction itself had on effect on mRNA expression of $(\boldsymbol{H})$ Gadd45 $\alpha$, (I) Gadd45 $\beta$, and ( $\boldsymbol{J})$ Gadd45 $\gamma(N=4$ per group). $\boldsymbol{K}$, Additionally, Gadd45 $\alpha$ shRNA had no effect on other two family members. $\boldsymbol{L}$, Gadd $45 \beta$ shRNA had no effect on other two family members and $(\boldsymbol{M})$ Gadd45 $\gamma$ shRNA had no effect on other two family members $(N=3$ per group for $\boldsymbol{K}-\boldsymbol{M})$. PreCS, Contextual freezing before first CS; AvgCS, average freezing at test. Error bars represent SEM. ${ }^{*} p<0.05,{ }^{* *} p<0.01$.

used established protocols (Lin et al., 2011) to design and test shRNAs against all three members of the Gadd45 family. In independent experiments, each shRNA was infused into the PLPFC $\sim 1$ week before behavioral training (Fig. $1 D-G$ ). A decrease in the protein level of all three Gadd45 family members was confirmed by Western blot (Fig. $1 H-J ; t_{(2)}=67.92$, Control vs Gadd $45 \alpha$ shRNA, $p=0.0002 ; t_{(2)}=4.42$ Control vs Gadd $45 \beta$ shRNA, $p=0.0474 ; t_{(2)}=5.48$ Control vs Gadd $45 \gamma$ shRNA, $p=$ 0.0317 , unpaired $t$ test). There was no effect of knockdown of any member of the Gadd 45 family on the acquisition of freezing behavior during cued fear learning (data not shown). Knockdown of Gadd $45 \alpha$ and Gadd $45 \beta$ had no effect on memory retention. In contrast, Gadd $45 \gamma$ shRNA-treated mice exhibited a significant impairment in fear memory when tested $24 \mathrm{~h}$ later (Fig. $1 K-M$; $F_{(3,34)}=42.15,{ }^{* * * *} p<0.0001$; Sidak post hoc analysis: FC Control vs FC Gadd $45 \gamma$ shRNA, ${ }^{* * * *} p<0.0001$, one-way ANOVA), with no effect on short-term memory when tested $2 \mathrm{~h}$ posttraining, further implying a selective role for Gadd $45 \gamma$ in the PLPFC in the consolidation phase of cued fear memory formation (Fig. $2 A-C$ ). There was no effect of Gadd $45 \gamma$ shRNA on locomotor or anxiety-like behavior in the open-field test (Fig. $2 D-F)$. Given the connection between Gadd $45 \beta$ and inflammatory signaling (Jarome et al., 2015), we also performed a PBSinjection control experiment, which revealed no nonspecific effect of lentivirus infusion on Gadd45 family member mRNA expression (Fig. $2 G-J$ ). Considering the evolutionarily conserved

(Figure legend continued.) mouse transcript. $\boldsymbol{M}$, There was a significant decrease in the percentage freezing for animals infused with Gadd45 $\gamma$ shRNA compared with control at test $(N=$ 8-14 per group). FC, Fear conditioned; (TX, context exposure; CS, conditioned stimulus (tone); US, unconditioned stimulus (shock); PreCS, contextual freezing before first CS; AvgCS, average freezing at test. Error bars represent SEM. ${ }^{*} p<0.05,{ }^{* *} p<0.001,{ }^{* * *} p<0.0001$. nature of the three Gadd45 family members, as well as their sequence similarity, we next determined whether there was an influence of individual gene knockdown on the mRNA expression of the other Gadd45 family members. Additionally, we confirmed that each shRNA is specific to the Gadd 45 family member it was designed against, and does not influence expression of the other two genes, further confirming the high degree of specificity of our shRNA design (Fig. $2 K-M ; F_{(3,8)}=7.53, p=0.01$; Sidak post hoc analysis: Gadd $45 \alpha$ shRNA vs control, $p=0.032 ; F_{(3,8)}=10.11$, $p=0.004$; Sidak post hoc analysis: Gadd $45 \beta$ shRNA vs control, $p=0.042 ; F_{(3,8)}=15.19, p=0.001$; Sidak post hoc analysis: Gadd $45 \gamma$ shRNA vs control, $p=0.001$, one-way ANOVA). Together, these data demonstrate a selective and critical role for Gadd $45 \gamma$, but not Gadd $45 \alpha$ or Gadd $45 \beta$, within the PLPFC in the regulation of cued fear memory.

\section{Cued fear learning leads to two peaks of IEG expression in} the PLPFC

We next used a candidate gene approach to examine whether Gadd $45 \gamma$ influences IEG expression and the formation of fear memory. The IEGs Arc, c-Fos, and Npas4 represented prime choices because of their well known role in regulating fear-related learning and memory (Tischmeyer and Grimm, 1999; Ploski et al., 2008, 2011; Katche et al., 2010). We also included a newly discovered IEG, Cyr61, as it has recently been shown to be highly expressed in the brain and to be induced by neural activity (Albrecht et al., 2000; Sakuma et al., 2015). An analysis of the temporal pattern of learning-induced IEG mRNA expression revealed that Arc, c-Fos, Npas4, and Cyr61 exhibited two significant peaks of expression in the PLPFC in response to cued fear conditioning (Fig. $3 A-D ; t_{(8)}=3.49$, CTX $0 \mathrm{~h}$ vs FC $0 \mathrm{~h}, p=0.008$ and $t_{(8)}=2.44$, CTX $5 \mathrm{~h}$ vs FC $5 \mathrm{~h}, p=0.040$ for Arc; $t_{(8)}=2.78$, CTX $0 \mathrm{~h}$ vs FC $0 \mathrm{~h}, p=0.024$ and $t_{(8)}=2.28$, CTX $5 \mathrm{~h}$ vs FC $5 \mathrm{~h}$, 
Arc

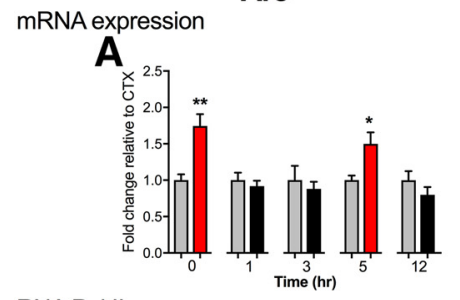

RNA Pol II occupancy

E

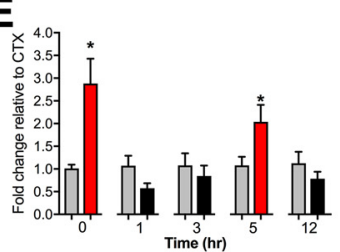

$\gamma \mathrm{H} 2 \mathrm{~A} . \mathrm{X}$ occupancy

I

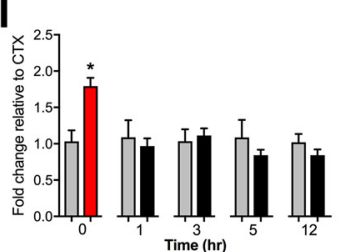

Topo II $\beta$ occupancy

M

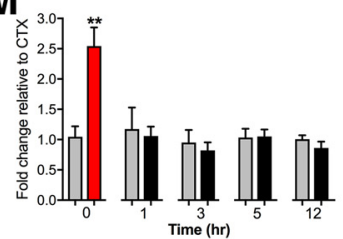

c-Fos

B



$\mathbf{F}$

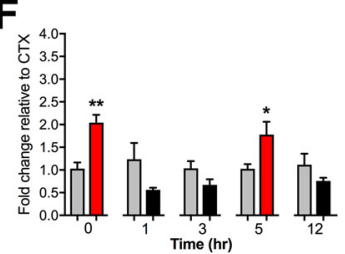

J

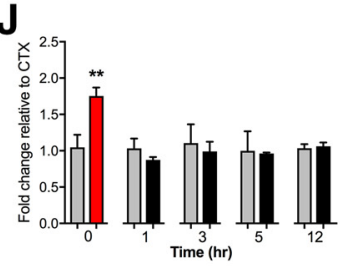

N

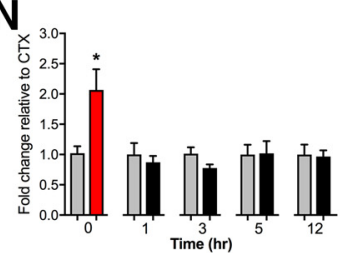

Npas4

C

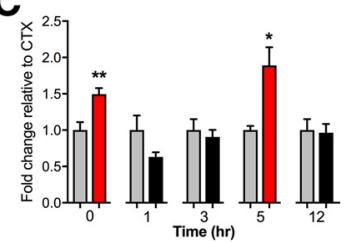

G

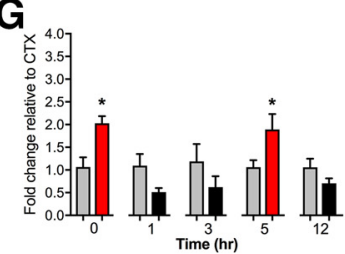

K

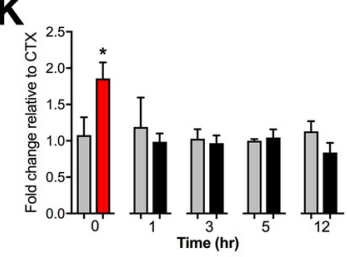

0

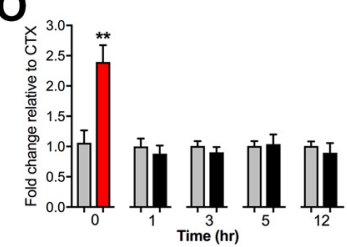

Cyr61

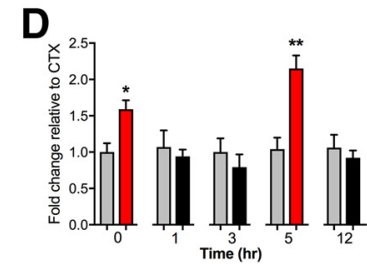

$\mathrm{H}$

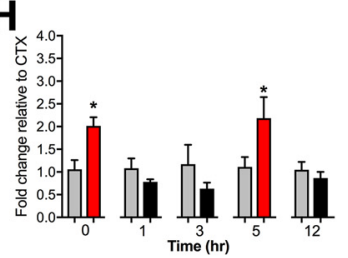

L

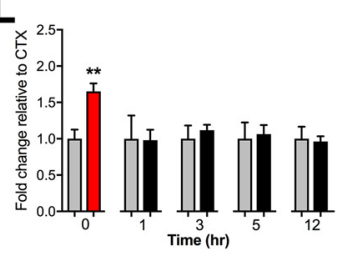

$\mathbf{P}$

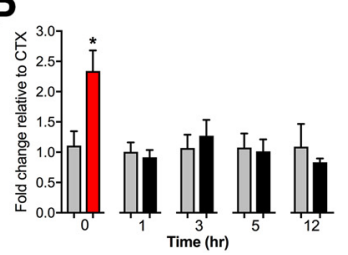

Figure 3. Fear learning leads to a distinct pattern of IEG expression in the PLPFC regulated by DSBs. All panels show fold-change for fear conditioned animals which is calculated relative to each group's own context control at that time point. $\boldsymbol{A}$, There was a significant increase in mRNA expression 0 and $5 \mathrm{~h}$ post-fear conditioning for Arc, $(\boldsymbol{B})$ C-Fos, ( $(\boldsymbol{C})$ Npas4, and (D) Cyr61. E, The IEG mRNA induction was associated with a significant increase in RNA Pol Il occupancy 0 and $5 \mathrm{~h}$ as well post-fear conditioning for Arc, $(\boldsymbol{F})$ C-Fos, $(\boldsymbol{G})$ Npas4, and $(\boldsymbol{H})$ Cyr61. I, There was also a significant increase in $\gamma \mathrm{H} 2 \mathrm{~A}$.X occupancy immediately

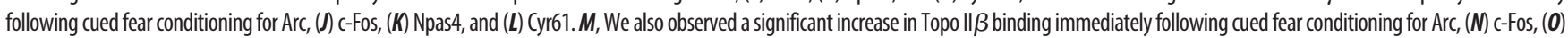
Npas4, and $(\boldsymbol{P})$ Cyr61. $N=4-6$ per group for all panels. FC, Fear conditioned; (TX, context exposure. Error bars represent SEM. ${ }^{*} p<0.05,{ }^{* *} p<0.01$.

$p=0.048$ for c-Fos; $t_{(8)}=3.66$, CTX $0 \mathrm{~h}$ vs FC $0 \mathrm{~h}, p=0.006$ and $t_{(8)}=2.82$, CTX $5 \mathrm{~h}$ vs FC $5 \mathrm{~h}, p=0.023$ for Npas $4 ; t_{(8)}=3.26$, CTX $0 \mathrm{~h}$ vs FC $0 \mathrm{~h}, p=0.012$ and $t=3.92$, CTX $5 \mathrm{~h}$ vs FC $5 \mathrm{~h}, p=$ 0.002 for Cyr61, unpaired $t$ test), which is concomitant with a similar pattern of RNA Polymerase II (RNA pol II) occupancy within the promoter region of all four IEGs (Fig. $2 E-H ; t_{(6)}=$ 3.36, CTX 0 h vs FC 0 h, $p=0.015$ and $t_{(6)}=2.53$, CTX $5 \mathrm{~h}$ vs FC $5 \mathrm{~h}, p=0.035$ for Arc; $t_{(6)}=4.65$, CTX $0 \mathrm{~h}$ vs FC $0 \mathrm{~h}, p=0.004$ and $t_{(6)}=2.92$, CTX $5 \mathrm{~h}$ vs FC $5 \mathrm{~h}, p=0.019$ for c-Fos; $t_{(6)}=3.64$, CTX 0 h vs FC $0 \mathrm{~h}, p=0.011$ and $t_{(6)}=2.50$, CTX $5 \mathrm{~h}$ vs FC $5 \mathrm{~h}$, $p=0.037$ for Npas $4 ; t_{(6)}=3.44$, CTX 0 h vs FC 0 h, $p=0.014$ and $t_{(6)}=2.36$ CTX $5 \mathrm{~h}$ vs FC $5 \mathrm{~h}, p=0.046$ for Cyr61, unpaired $t$ test). This is reminiscent of earlier observations by Igaz et al., 2002 in which two waves of transcription, one occurring immediately after training and one occurring 3-6 h later, were shown to be required for the formation of hippocampal-dependent fear memory (Igaz et al., 2002), as well as a variety of other reports in which double IEG peaks have been observed in the context of learning (Katche et al., 2010; Lefer et al., 2012). However, in those studies, the molecular mechanisms underlying multiple waves of IEG expression were not determined.

Learning-induced IEG expression is regulated by DSBs and a time-dependent increase in DNA methylation

Emerging evidence suggests that DNA double-strand breaks (DSBs) and related DNA repair pathways may also be required for the rapid induction of IEG expression (Madabhushi et al., 2015; Su et al., 2015). These processes interact with dynamic changes in DNA methylation (Pastink et al., 2001; O'Hagan et al., 2008; Wossidlo et al., 2010; Niehrs and Schäfer, 2012; Morano et al., 2014). In line with this, Gadd $45 \beta$ has been shown to be recruited to genomic loci in response to stimuli that generate DSBs (i.e., radiation; Xiao et al., 2000; Smith et al., 2011). Based on these observations, we questioned whether members of the Gadd45 family would mediate the interaction between DSBs, DNA methylation, and DNA repair to influence IEG expression and memory formation. To first determine whether these IEGs are subject to DSBs in the adult brain, we probed their proximal promoters for evidence of learning-induced DSBs following fear conditioning. $\gamma \mathrm{H} 2 \mathrm{~A}$.X has been shown to be an excellent marker for DSBs (Kuo and Yang, 2008), and Topo II $\beta$ is known to generate DSBs and is involved in the recruitment of DNA repair enzymes (Wossidlo et al., 2010; Calderwood, 2016). Indeed, previous work has shown a critical role for Topo II $\beta$ in the regulation of IEG expression (Madabhushi et al., 2015). ChIP assay revealed a significant increase in both $\gamma \mathrm{H} 2 \mathrm{~A} . \mathrm{X}$ (Fig. $3 I-L ; t_{(8)}=4.07$, CTX $0 \mathrm{~h}$ vs FC $0 \mathrm{~h} p=0.003$ for Arc; $t_{(8)}=3.52$, CTX $0 \mathrm{~h}$ vs FC $0 \mathrm{~h}, p=$ 0.008 for c-Fos; $t_{(8)}=2.31$, CTX 0 h vs FC 0 h, $p=0.049$ for Npas4; $t_{(8)}=3.81$, CTX 0 h vs FC 0 h, $p=0.005$ for Cyr61, unpaired $t$ test) and Topo II $\beta$ (Fig. $3 M-P ; t_{(8)}=3.68$, CTX $0 \mathrm{~h}$ vs FC 0 h, $p=0.006$ for Arc; $t_{(8)}=2.39$, CTX 0 h vs FC 0 h, $p=0.043$ 
Arc

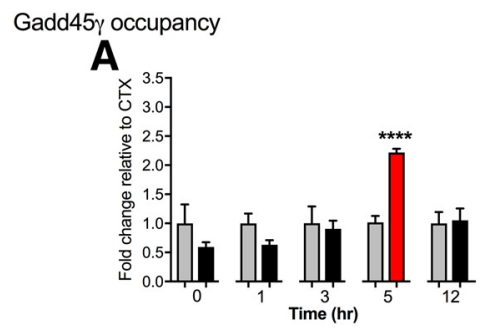

DNMT3A occupancy

E

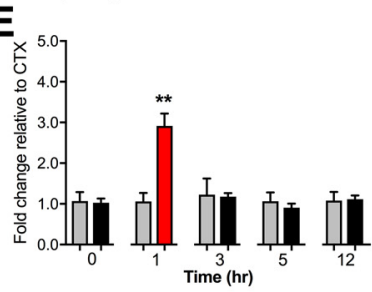

5-mC level

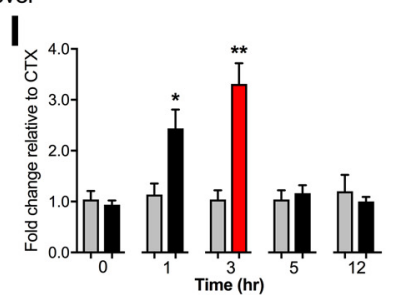

B

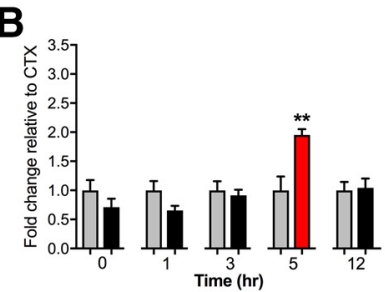

$\mathbf{F}_{\times}$
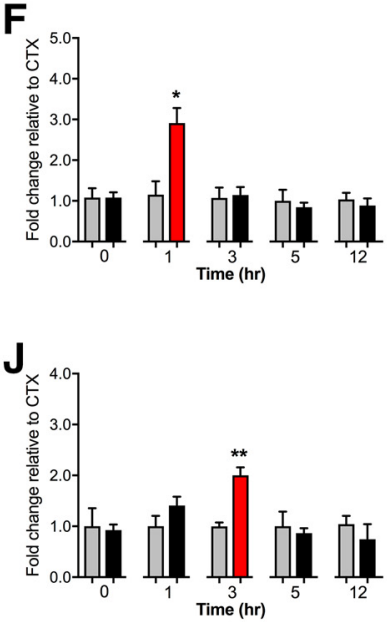

Npas4
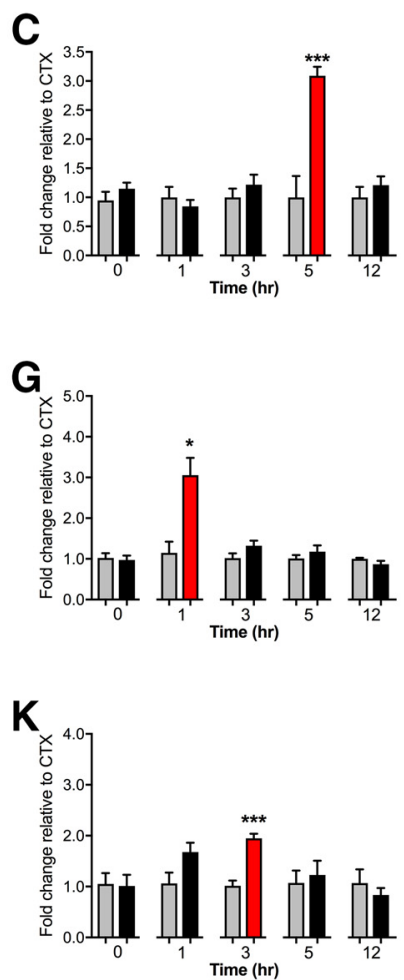

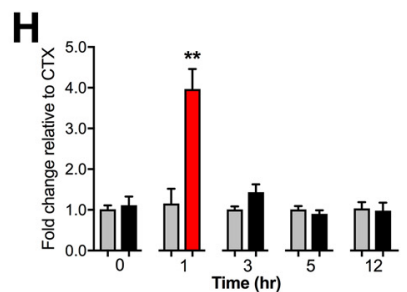

Cyr61
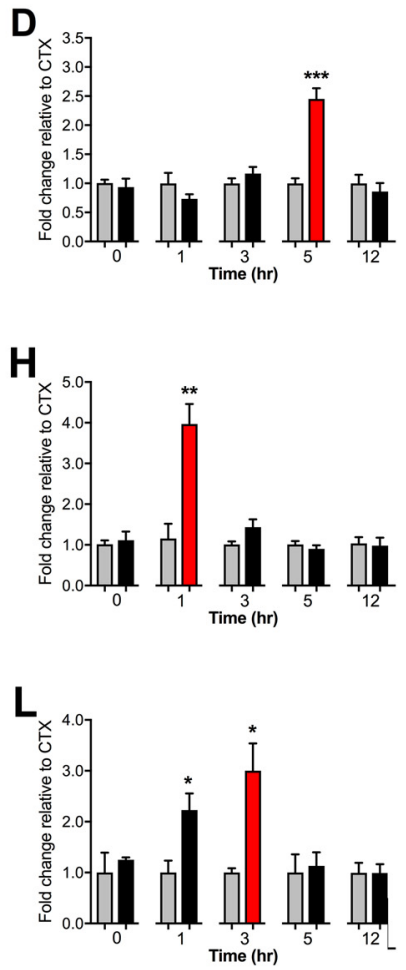

Figure 4. Fear conditioning associated DSBs are followed by time-dependent increases in DNA methylation, and later by Gadd45 $\gamma$ recruitment. There was a significant increase in Gadd45 $\gamma$ occupancy at $5 \mathrm{~h}$ for $(\boldsymbol{A}) \operatorname{Arc},(\boldsymbol{B})$ C-Fos, (C) Npas4, and (D) Cyr61. $\boldsymbol{E}$, A significant increase in DNMT3A occupancy was observed $1 \mathrm{~h}$ after fear conditioning for Arc, $(\boldsymbol{F}) \boldsymbol{C}-\mathrm{Fos},(\boldsymbol{G}) \mathrm{Npas} 4$, and $(\boldsymbol{H})$ Cyr61. $\boldsymbol{I}$, A significant increase in 5-mC levels as measured by methylated DNA immunoprecipitation was found post-fear conditioning for Arc, $(\boldsymbol{J}) \boldsymbol{C}$-Fos, $(\boldsymbol{K})$ Npas4, and $(\boldsymbol{L})$ Cyr61. $N=6$ per group for all panels. FC, Fear conditioned; CTX, context exposure. Error bars represent SEM. ${ }^{*} p<0.05,{ }^{* *} p<0.01,{ }^{* * *} p<0.001,{ }^{* * * *} p<0.0001$.

for c-Fos; $t_{(8)}=3.51$, CTX 0 h vs FC 0 h, $p=0.008 ; t_{(8)}=2.67$ CTX 0 h vs FC 0 h, $p=0.028$, unpaired $t$ test) binding within the promoter of all four IEGs immediately following fear conditioning, corresponding to the first peak of IEG expression, but not at the second.

Given that Topo II $\beta$ is associated with the induction and rapid repair of DSBs, which occurs within the first hour post-training, we questioned the underlying mechanism of the second peak of IEG expression. To test the hypothesis that the formation of DSBs leads to the recruitment of Gadd $45 \gamma$, we performed ChIP to determine the time-dependent recruitment of Gadd $45 \gamma$ to the promoter of each IEG in response to fear learning. There was a significant increase in Gadd $45 \gamma$ binding at the $5 \mathrm{~h}$ time point for all IEGs (Fig. $4 A-D ; t_{(8)}=10.17$, CTX $5 \mathrm{~h}$ vs FC $5 \mathrm{~h}$, ${ }^{* * *} p<$ 0.0001 for Arc; $t_{(8)}=4.24$, CTX 5 h vs FC $5 \mathrm{~h}, p=0.003$ for c-Fos; $t_{(8)}=6.02$, CTX $5 \mathrm{~h}$ vs FC $5 \mathrm{~h}, p=0.0003$ for Npas $4 ; t_{(8)}=5.99$, CTX 5 h vs FC 5 h, $p=0.0003$ for Cyr61, unpaired $t$ test). Given that DSBs are repaired before the second wave of transcription, we considered whether there are other mechanisms that serve to maintain the promoter region of these IEGs in a poised state following the repair of the originating DSB, in order for the second wave of transcription to proceed. DNA methylation has been shown to increase at sites of DSBs (Morano et al., 2014) and changes in DNA methylation are associated with memory formation (Day and Sweatt, 2010). We therefore assessed the DNA methylation state at these loci. DNMT3A ChIP and MeDIP revealed a significant increase in DNMT3A occupancy at the site of DSBs in all loci after the first peak of IEG expression (Fig. 4E-H; $t_{(8)}=4.5$, CTX $1 \mathrm{~h}$ vs FC $1 \mathrm{~h}, p=0.002$ for Arc; $t_{(8)}=3.29$, CTX
$1 \mathrm{~h}$ vs FC $1 \mathrm{~h}, p=0.011$ for c-Fos; $t_{(8)}=3.32$, CTX $1 \mathrm{~h}$ vs FC $1 \mathrm{~h}$, $p=0.011$ for Npas $4 ; t_{(8)}=4.17$, CTX 1 h vs FC $1 \mathrm{~h}, p=0.003$ for Cyr61), which was followed by an increase in $5-\mathrm{mC}$ up to $3 \mathrm{~h}$ post-fear conditioning (Fig. $4 I-L ; t_{(8)}=2.65$, CTX $1 \mathrm{~h}$ vs FC $1 \mathrm{~h}$, $p=0.029$ and $t_{(8)}=4.29$, CTX $3 \mathrm{~h}$ vs FC $3 \mathrm{~h}, p=0.003$ for Arc; $t_{(8)}=4.88$, CTX $3 \mathrm{~h}$ vs FC $3 \mathrm{~h}, p=0.001$ for c-Fos; $t_{(8)}=6.7$, CTX $3 \mathrm{~h}$ vs FC $3 \mathrm{~h}, p=0.0002$ for Npas $4 ; t_{(8)}=2.74$, CTX $1 \mathrm{~h}$ vs FC $1 \mathrm{~h}$, $p=0.026$ and $t_{(8)}=2.97$, CTX $3 \mathrm{~h}$ vs FC $3 \mathrm{~h}, p=0.018$ for Cyr61, unpaired $t$ test). The data imply a general increase in learningrelated DNA methylation that follows the repair of learninginduced DSBs.

Gadd45 $\gamma$ regulates learning-induced IEG expression in a temporally specific manner through an interaction with DNA methylation

Bearing in mind that Gadd45 $\gamma$ binding occurred specifically at the $5 \mathrm{~h}$ time point, which matches the second wave of IEG expression, we next asked whether Gadd $45 \gamma$ is involved in the temporal regulation of IEG expression. Gadd $45 \gamma$ knockdown significantly reduced the occupancy of Gadd $45 \gamma$ (Fig. $5 A-D ; F_{(1,16)}=6.38$, $p=0.022$; Sidak post hoc analysis: control CTX $5 \mathrm{~h}$ vs control FC $5 \mathrm{~h}, p=0.007$ for Arc; $F_{(1,16)}=15.77, p=0.001$; Sidak post hoc analysis: control CTX 5 h vs control FC $5 \mathrm{~h}$, ${ }^{* * *} p<0.0001$ for c-Fos; $F_{(1,16)}=7.54, p=0.014$; Sidak post hoc analysis: control CTX 5 h vs control FC $5 \mathrm{~h}, p=0.002$ for Npas $4 ; F_{(1,16)}=8.38, p=$ 0.011; Sidak post hoc analysis: control CTX $5 \mathrm{~h}$ vs control FC $5 \mathrm{~h}$, $p=0.002$ for Cyr61, two-way ANOVA) and blocked IEG expression at the second peak only (Fig. $5 E-H ; F_{(1,15)}=6.57, p=0.021$; Sidak post hoc analysis: control CTX $5 \mathrm{~h}$ vs control FC $5 \mathrm{~h}, p=$ 
Arc

Gadd45\% occupancy

A

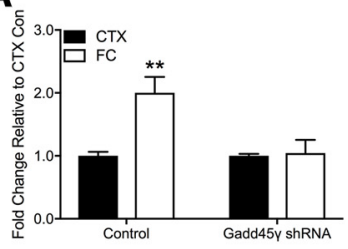

mRNA expression

$\mathbf{E}_{5}$

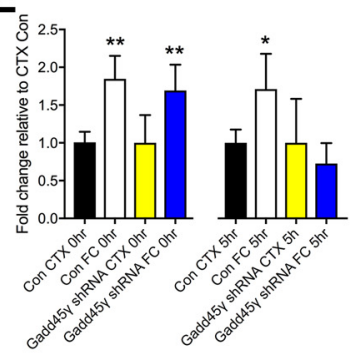

5-mC level

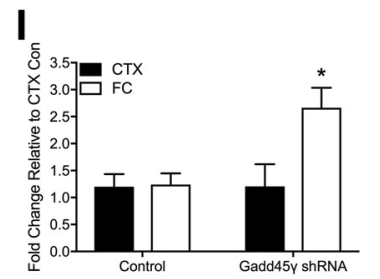

c-Fos
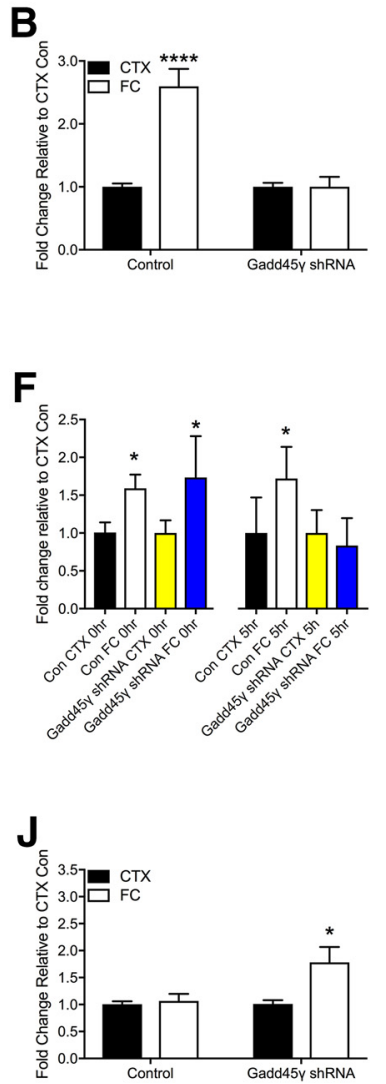

Npas4

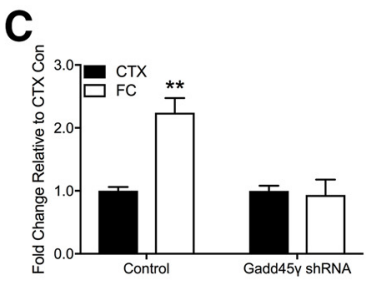

$\mathbf{G}_{5}$
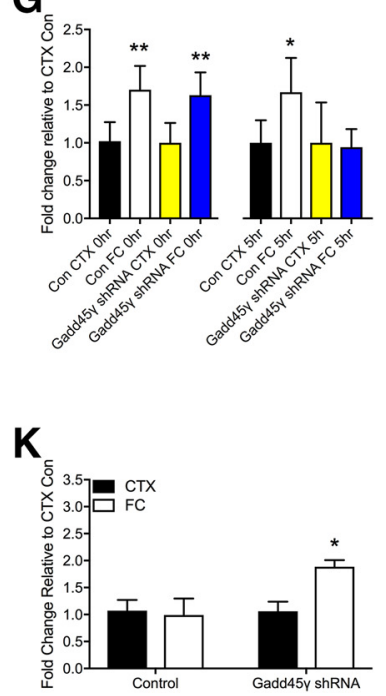

Cyr61

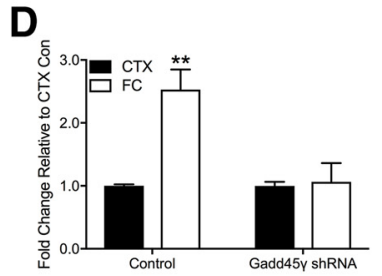

Figure 5. Gadd45 $\gamma$ regulates learning-induced IEG expression in a temporally specific manner through interaction with DNA methylation. Presence of Gadd45 $\gamma$ shRNA led to significantly less Gadd45 $\gamma$ occupancy at $(\boldsymbol{A}) \operatorname{Arc},(\boldsymbol{B})$ C-Fos, (C) Npas4, and (D) Cyr61. Gadd45 $\gamma$ knockdown also led to a significant decrease in mRNA expression at $5 \mathrm{~h}$ for $(\boldsymbol{E})$ Arc, $(\boldsymbol{F}) \boldsymbol{C}$-Fos, $(\boldsymbol{G})$ Npas4, and $(\boldsymbol{H})$ Cyr61, without any influence on mRNA expression of Arc, $c-F 0 s$, Npas4, and Cyr61 at $0 \mathrm{~h}$ time point $(\boldsymbol{E}-\boldsymbol{H})$. Gadd45 $\gamma$ shRNA infusion result in remaining high level of promoter DNA methylation at $5 \mathrm{~h}$ for (I) Arc, (J) C-Fos, (K) Npas4, and (L) Cyr61. $N=4-6$ per group for all panels. FC, Fear conditioned; CTX, context exposure. Error bars represent SEM. ${ }^{*} p<0.05,{ }^{* *} p<0.01$, ${ }^{* * *} p<0.001$, ${ }^{* * * *} p<0.0001$.

0.045 for $\operatorname{Arc} ; F_{(1,15)}=6.15, p=0.025$; Sidak post hoc analysis: control CTX $5 \mathrm{~h}$ vs control FC $5 \mathrm{~h}, p=0.029$ for $c$-Fos; $F_{(1,15)}=$ $5.67, p=0.031$; Sidak post hoc analysis: control CTX $5 \mathrm{~h}$ vs control FC $5 \mathrm{~h}, p=0.017$ for Npas $4 ; F_{(1,15)}=5.64, p=0.031$; Sidak post hoc analysis: control CTX $5 \mathrm{~h}$ vs control FC $5 \mathrm{~h}, p=0.008$ for Cyr61, two-way ANOVA). In addition, 5-mC levels declined sharply at the time point at which Gadd $45 \gamma$ was bound, whereas Gadd $45 \gamma$ knockdown led to persistently high levels of 5-mC (Fig. $5 I-L ; F_{(1,14)}=4.78, p=0.046$; Sidak post hoc analysis: Gadd $45 \gamma$ shRNA CTX 5 h vs Gadd $45 \gamma$ shRNA FC 5 h, $p=0.013$ for Arc; $F_{(1,14)}=5.47, p=0.035$; Sidak post hoc analysis: Gadd $45 \gamma$ shRNA CTX $5 \mathrm{~h}$ vs Gadd $45 \gamma$ shRNA FC $5 \mathrm{~h}, p=0.011$ for $\mathrm{c}-\mathrm{Fos} ; F_{(1,14)}=$ 5.01, $p=0.042$; Sidak post hoc analysis: Gadd $45 \gamma$ shRNA CTX $5 \mathrm{~h}$ vs Gadd $45 \gamma$ shRNA FC $5 \mathrm{~h}, p=0.017$ for Npas4; $F_{(1,14)}=9.82$, $p=0.007$; Sidak post hoc analysis: Gadd $45 \gamma$ shRNA CTX 5 h vs Gadd45 $\gamma$ shRNA FC $5 \mathrm{~h}, p=0.0003$ for Cyr61, two-way ANOVA). Together, these data suggest that although DSBs are required for the initial activation of the IEG expression, it is the second peak of IEG expression during the consolidation phase of memory that is critically regulated by Gadd $45 \gamma$-mediated changes in DNA methylation.

Gadd45y occupancy is necessary for the second wave of IEG expression and the consolidation of cued fear memory

To further reveal the mechanism by which Gadd $45 \gamma$ regulates the formation of fear memory, we manipulated Gadd $45 \gamma$ activity immediately before the second wave of IEG expression, without disturbing the first peak. There are no commercially available pharmacological Gadd45 $\gamma$ antagonists so we turned to an antibody decoy approach. This is a rapid and transient method to block Gadd45 $\gamma$ activity, which permits an examination of the precise temporal role of Gadd $45 \gamma$ during the consolidation phase of fear memory. A similar approach has previously been used to examine the role of BDNF in memory consolidation. The biological activity of Gadd $45 \gamma$ was temporally neutralized by infusing an anti-Gadd $45 \gamma$ antibody into the PLPFC region ( $1 \mu \mathrm{g} / \mathrm{side})$ before the second peak of IEG expression. Injection of the Gadd $45 \gamma$ antibody $3 \mathrm{~h}$ post-fear training (Fig. $6 A$ ) significantly impaired fear memory (Fig. $6 B ; F_{(4,21)}=6.02, p=0.002$; Sidak post hoc analysis: FC control vs FC Gadd45 $\gamma$ antibody, $p=0.036$, one-way ANOVA). Importantly, Gadd $45 \gamma$ occupancy at each IEG promoter was significantly reduced $5 \mathrm{~h}$ after fear training (Fig. $6 C-F ; F_{(1,12)}=10.4, p=0.007$, Sidak post hoc analysis: control CTX $5 \mathrm{~h}$ vs control FC $5 \mathrm{~h}, p=0.003$ for Arc; $F_{(1,12)}=$ $6.48, p=0.026$, Sidak post hoc analysis: control CTX $5 \mathrm{~h}$ vs control FC $5 \mathrm{~h}, p=0.021$ for $\mathrm{c}-\mathrm{Fos} ; F_{(1,12)}=8.47, p=0.013$, Sidak post hoc analysis: control CTX $5 \mathrm{~h}$ vs control FC $5 \mathrm{~h}, p=0.013$ for Npas4; $F_{(1,12)}=10.4, p=0.049$, Sidak post hoc analysis: control CTX $5 \mathrm{~h}$ vs control FC $5 \mathrm{~h}, p=0.023$ for Cyr61, two-way ANOVA), and this effect was accompanied by a reduction in the second peak of IEG mRNA expression (Fig. $6 G-J ; F_{(1,12)}=6.87$, 


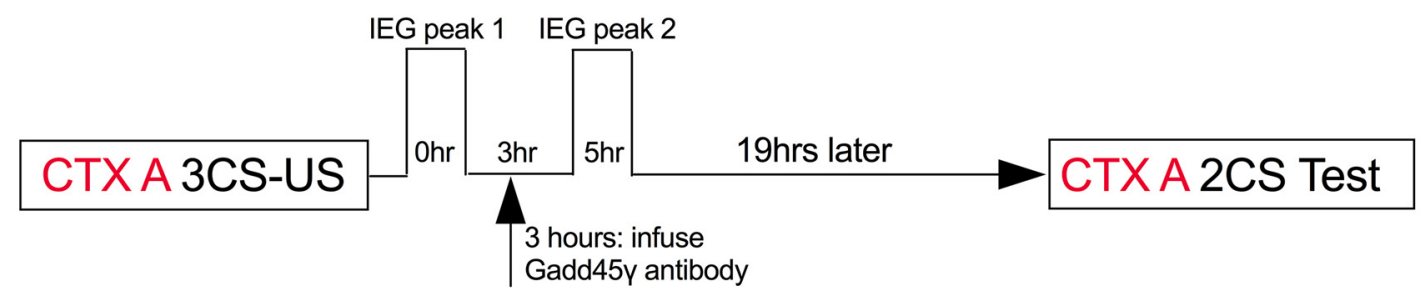

B
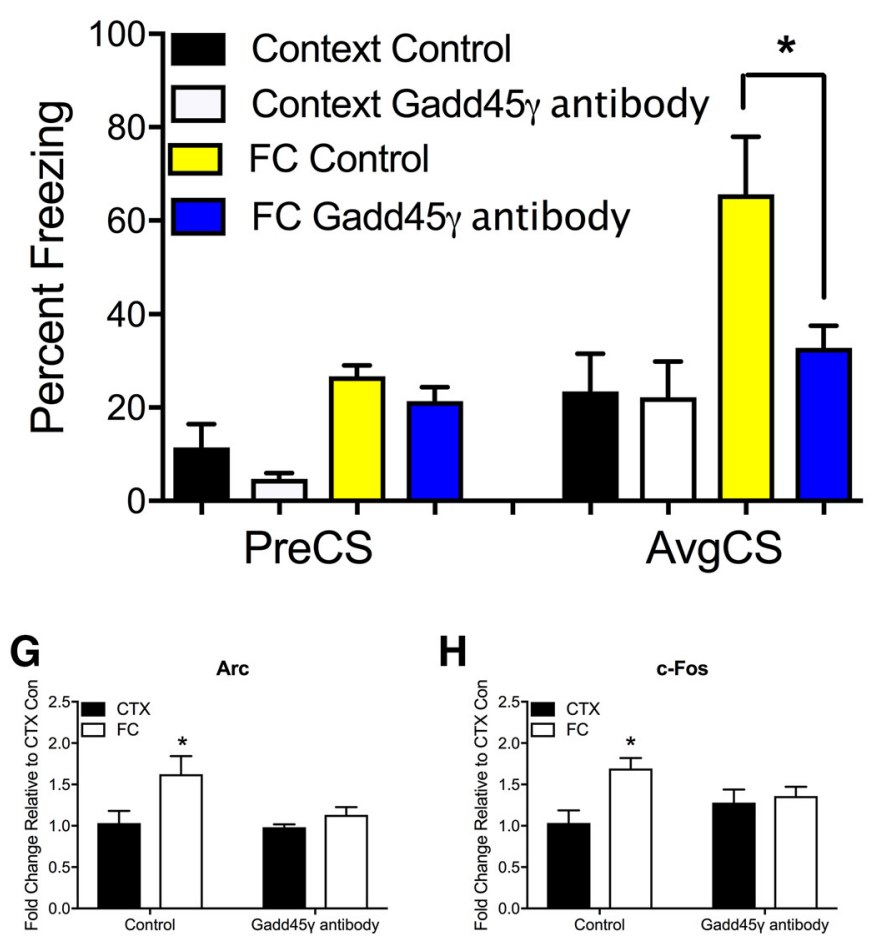

Gadd45 $\gamma$ antibody

H

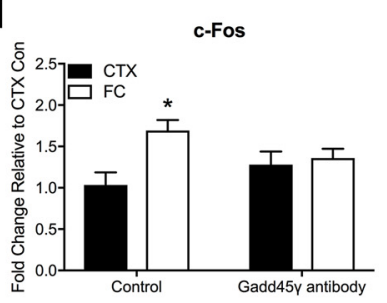

C
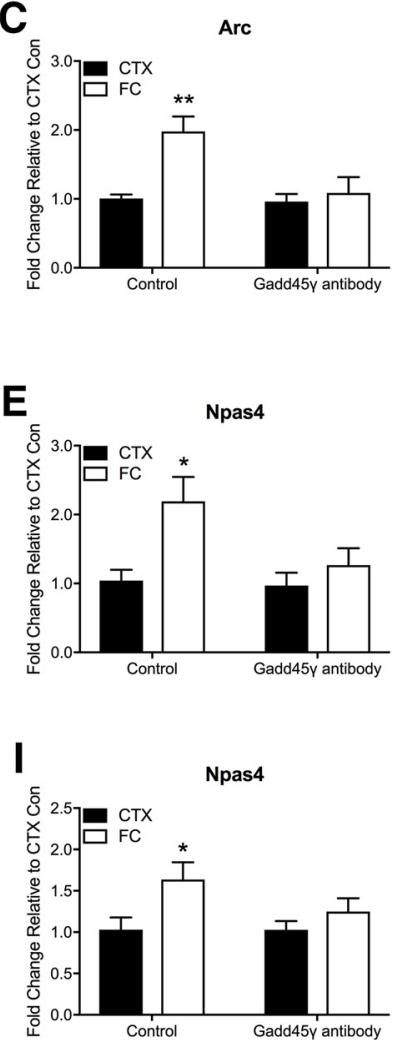

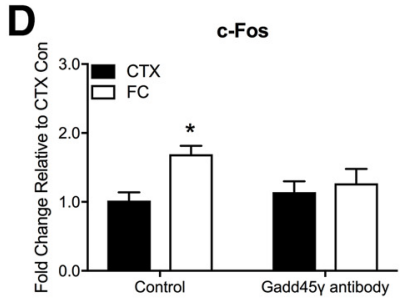

$\mathbf{F}$
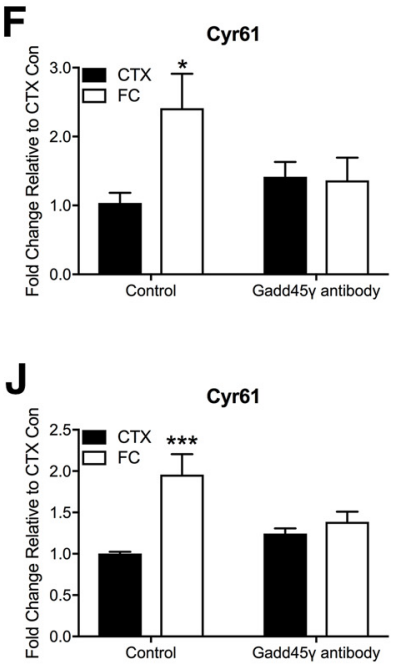

Figure 6. Gadd45 $\gamma$ is necessary for cued fear learning in a temporally specific manner. $\boldsymbol{A}$, Time course of behavioral training and anti-Gadd45 $\gamma$ antibody infusion. $\boldsymbol{B}$, There was a significant decrease in the percentage freezing for animals infused with Gadd45 $\gamma$-blocking antibody compared with control at test ( $N=7-8$ per group). Following antibody injection, there was a significant reduction in Gadd45 $\gamma$ occupancy at the promoter of $(\boldsymbol{C}) \operatorname{Arc},(\boldsymbol{D}) \mathrm{C}-\mathrm{Fos},(\boldsymbol{E})$ Npas4, and $(\boldsymbol{F})$ Cyr61. The induction of IEG mRNA expression was blocked at $5 \mathrm{~h}$ post-training compared with control (G) Arc, (H) C-Fos, (I) Npas4, and (J) Cyr61.N = 4 per group for $\boldsymbol{C}-\boldsymbol{J}$. FC, Fear conditioned; CTX, context exposure; CS, conditioned stimulus (tone); US, unconditioned stimulus (shock); PreCS, contextual freezing before first CS; AvgCS, average freezing at test. Error bars represent $S E M .{ }^{*} p<0.05,{ }^{* *} p<0.01,{ }^{* * *} p<0.001$.

$p=0.022$, Sidak post hoc analysis: control CTX 5 h vs control FC $5 \mathrm{~h}, p=0.024$ for $A r c ; F_{(1,12)}=7.11, p=0.021$, Sidak post hoc analysis: control CTX $5 \mathrm{~h}$ vs control FC $5 \mathrm{~h}, p=0.011$ for $c$-Fos; $F_{(1,12)}=6.77, p=0.023$, Sidak post hoc analysis: control CTX $5 \mathrm{~h}$ vs control FC $5 \mathrm{~h}, p=0.039$ for Npas4; $F_{(1,12)}=15.1, p=0.002$, Sidak post hoc analysis: control CTX $5 \mathrm{~h}$ vs control FC $5 \mathrm{~h}, p=$ 0.0009 for Cyr61, two-way ANOVA). Together, these data demonstrate the temporal requirement of Gadd $45 \gamma$ binding for the second peak of IEG expression, and suggest that this is critically important for memory consolidation.

Temporally controlled knockdown of Cyr61 impairs the formation of fear memory

With the exception of Cyr61, each of the candidate IEG have previously been shown to influence the formation of fear memory (Albrecht et al., 2000; Igaz et al., 2002). To extend these findings to include the novel IEG, Cyr61, we designed and validated a DsiRNA directed against Cyr61. We infused two different concentrations of the Cyr61 DsiRNA to determine the most efficient knockdown of Cyr61 in the PLPFC following the same behavioral timeline as the Gadd45 $\gamma$ antibody experiment (Fig. 7A). Cyr61 DsiRNA (100 nM) administered after the first peak of Cyr61 expression led to a significant impairment in fear memory, although notably to a lesser degree than Gadd45 $\gamma$ knockdown (Fig. $7 B ; F_{(4,27)}=6.17 p=0.001$; Sidak post hoc analysis: FC control vs FC DsiRNA $100 \mathrm{~nm}, p=0.035$, one-way ANOVA) by significantly inhibited Cyr61 mRNA expression (Fig. $7 C ; F_{(1,16)}=7.09$, $p=0.017$; Sidak post hoc analysis: CTX control vs FC control, $p=$ 0.027, two-way ANOVA). In a separate experiment, we used a lentiviral packaged Cyr61 shRNA. Knockdown of Cyr61 led to a similar impairment in fear memory, which strongly indicates a functional role for this novel, brain-enriched IEG in fear-related learning and memory (Figs. $1 D, 7 D-F ; F_{(3,24)}=27.37,{ }^{\star * \star *} p<$ 0.0001; Sidak post hoc analysis: FC Control vs FC Cyr61 shRNA, $p=0.002$, two-way ANOVA).

Inhibition of DSB repair also impairs the formation of fear memory

Etoposide is a well established inhibitor of Topo II $\beta$ that traps the enzyme at DSB sites and prevents their repair (Madabhushi et al., 
A

A IEG peak 1 IEG peak 2

\section{CTXA 3CS-US}<smiles>CCCCO</smiles>

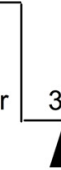

$3 \mathrm{hr} 5$

3 hours: infuse

Cyr61 DsiRNA

B

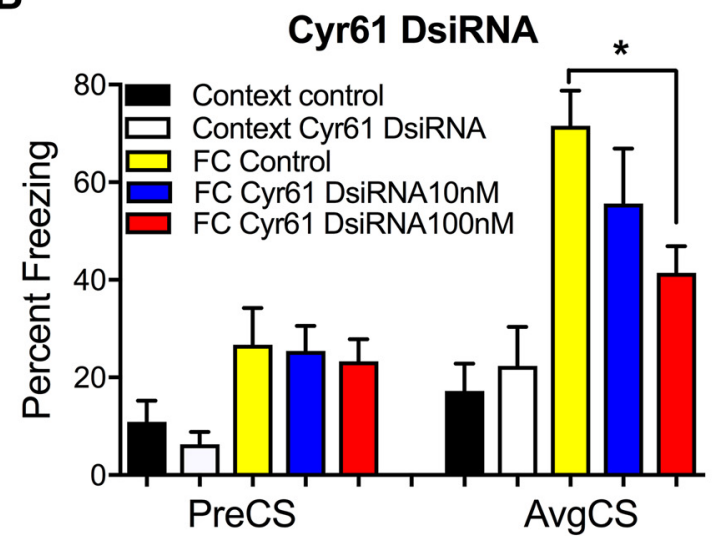

C

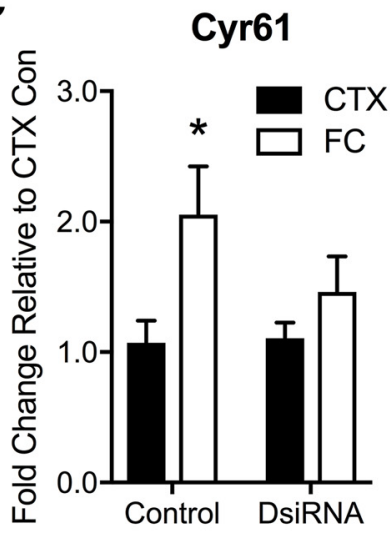

D

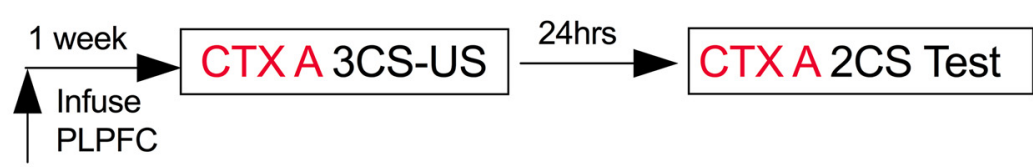

E

\section{Cyr61 shRNA fear acquisition}

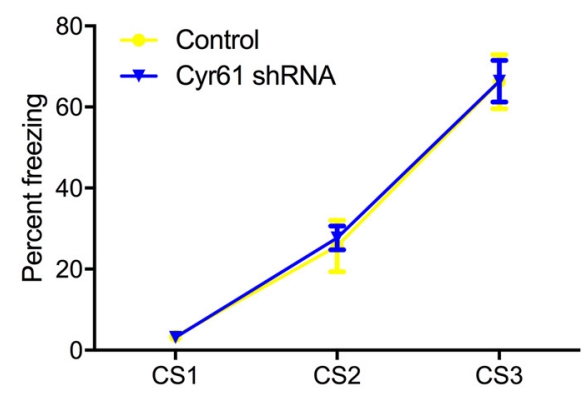

F

\section{Cyr61 shRNA fear memory}

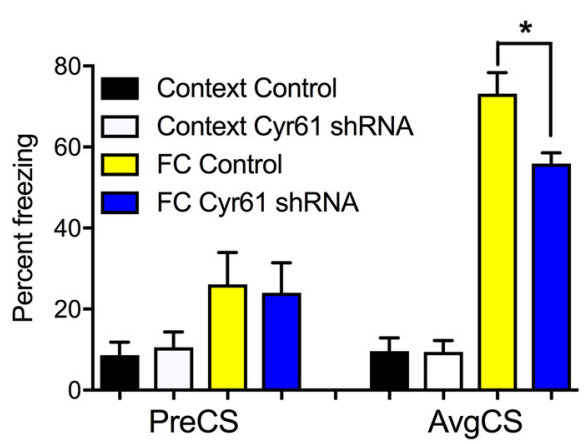

Figure 7. Cyr61 mRNA expression within PLPFC is necessary for cued fear learning. $A$, Time course of behavioral training and Cyr61 DsiRNA infusion. $B$, PLPFC infusion of Cyr61 DsiRNA (100 nm) administered $3 \mathrm{~h}$ after fear training blocks fear memory consolidation ( $N=7-8$ per group). $C$, Cyr61 DsiRNA $(100 \mathrm{~nm})$ also significantly reduced Cyr61 $\mathrm{mRNA}$ expression at $5 \mathrm{~h}$ post-fear training $(n=$ 5 per group). $\boldsymbol{D}$, Time course of behavioral training and shRNA infusion. $\boldsymbol{E}$, There were no significant differences between the Cyr61 shRNA and control groups during fear acquisition. $\boldsymbol{F}$, There was a significant decrease in the percentage freezing for animals infused with Cyr61 shRNA compared with control at test ( $N=7-8$ per group). FC, Fear conditioned; CTX, context exposure. Error bars represent SEM. ${ }^{*} p<0.05$.

2015). If DSBs associated with the first peak of IEG expression are repaired before the second peak of IEG expression, and this is necessary for establishing the poised state of IEG promoters, then administration of etoposide into the PLPFC should inhibit the second peak and impair fear memory. We first performed a doseresponse experiment, which suggested that a high dose of etoposide $(0.1 \mu \mathrm{g})$ but not a low dose (1 ng) administered into the PLPFC $2 \mathrm{~h}$ before training impaired the consolidation of fear memory resulting in a memory defect $24 \mathrm{~h}$ after training (data not shown). This finding was subsequently replicated in a larger cohort, confirming that etoposide infusion had no effect on fear acquisition, but significantly impaired fear memory when tested 24 h later (Fig. $8 A-C ; F_{(3,34)}=24.17,{ }^{* * *} p<0.001$; Sidak post hoc analysis: FC control vs FC etoposide, $p=0.001$, two-way ANOVA). In separate cohorts of mice, we also found that etoposide treatment significantly inhibited the accumulation of 5-mC at $3 \mathrm{~h}$ post-training (Fig. $8 D-G ; F_{(1,12)}=5.16, p=0.042$; Sidak post hoc analysis: control CTX $3 \mathrm{~h}$ vs control FC $3 \mathrm{~h}, p=0.019$ for Arc; $F_{(1,12)}=6.69, p=0.024$; Sidak post hoc analysis: control CTX $3 \mathrm{~h}$ vs control FC $3 \mathrm{~h}, p=0.031$ for c-Fos; $F_{(1,12)}=7.30, p=$ 0.019; Sidak post hoc analysis: control CTX $3 \mathrm{~h}$ vs control FC $3 \mathrm{~h}$, $p=0.017$ for Npas4; $F_{(1,12)}=6.11, p=0.029$; Sidak post hoc analysis: control CTX $3 \mathrm{~h}$ vs control FC $3 \mathrm{~h}, p=0.048$ for Cyr61; two-way ANOVA), as well as Gadd45 $\gamma$ binding at the $5 \mathrm{~h}$ time point (Fig. $8 H-K ; F_{(1,12)}=8.3, p=0.014$; Sidak post hoc analysis: 
A

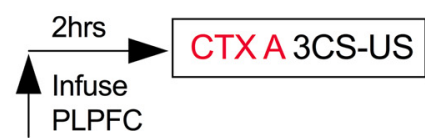

B

Fear acquisition

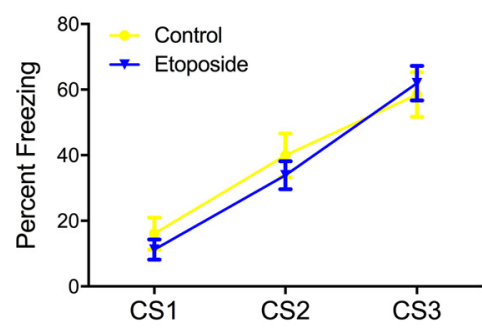

H

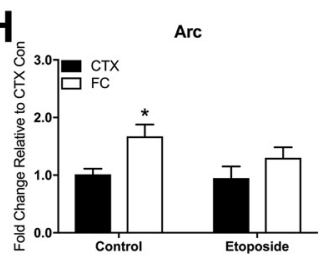

L

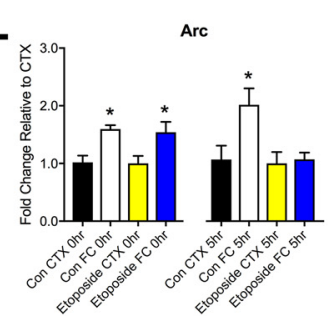

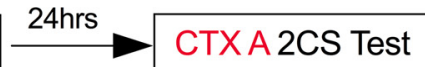

CTXA2CS Test

C

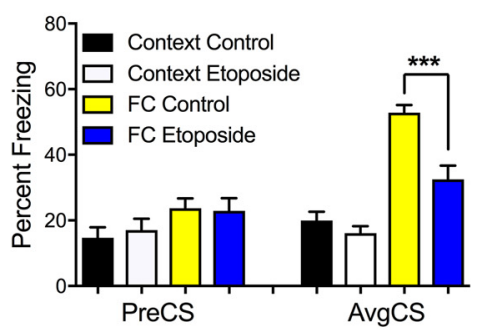

I

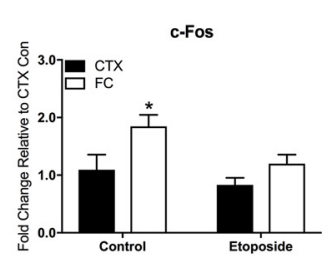

M

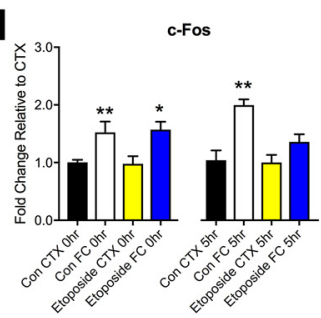

D

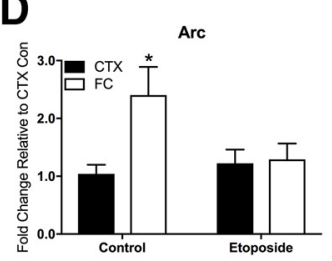

F Npas4
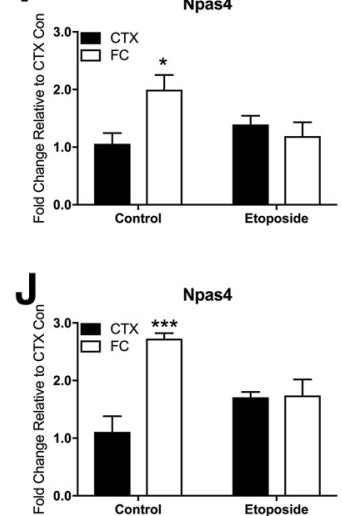

K

$\mathbf{N}$

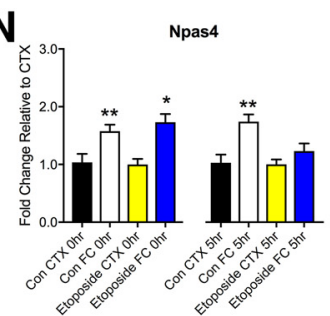

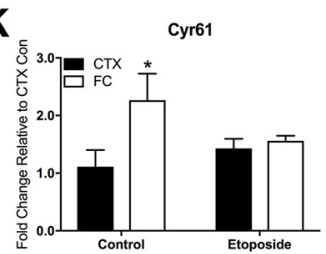

E



G

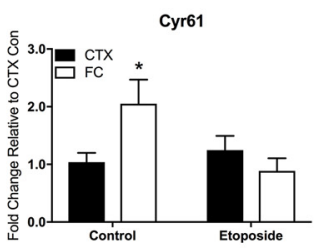

o

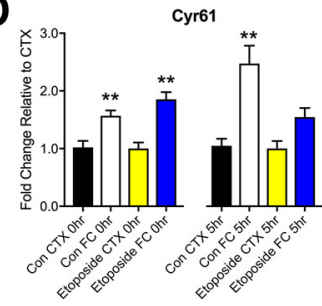

Figure 8. Etoposide infusion into the PLPFC inhibits fear memory formation by blocking repair of DSBs. $A$, Time course of behavioral training and etoposide infusion. $\boldsymbol{B}$, There were no significant differences between etoposide $(0.1 \mu \mathrm{g} / \mathrm{side})$ and control groups in percentage freezing during fear acquisition. $C$, There was a significant decrease in the percentage freezing for animals infused with etoposide compared with control at test ( $N=9-12$ per group). $\boldsymbol{D}$, Etoposide infusion blocked the temporal accumulation of 5-mC within the promoter region of Arc, $(\boldsymbol{E})$ c-Fos, $(\boldsymbol{F})$ Npas4, and $(\boldsymbol{G})$ Cyr61. $\boldsymbol{H}$, Etoposide infusion also inhibited Gadd45 $\gamma$ occupancy at promoter of Arc at the $5 \mathrm{~h}$ time point, $(\boldsymbol{I})$ c-Fos, (J) Npas4, and (K) Cyr61. Etoposide led to a significant decrease in mRNA at $5 \mathrm{~h}$ post-training $(\boldsymbol{L}) \operatorname{Arc}(\boldsymbol{M})$ C-Fos, $(\boldsymbol{N})$ Npas4, and $(\boldsymbol{0})$ Cyr61. Etoposide infusion had no effect on Arc, c-Fos, Npas4, and Cyr61 mRNA expression at the $0 \mathrm{~h}$ time point $(\boldsymbol{L}-\mathbf{0})$. $N=4$ per group for $\boldsymbol{D}-\mathbf{0}$. FC, Fear conditioned; CTX, context exposure. Error bars represent SEM. ${ }^{*} p<0.05,{ }^{* *} p<0.01,{ }^{* * *} p<0.001$.

control CTX 5 h vs control FC 5 h, $p=0.041$ for Arc; $F_{(1,12)}=$ $8.43, p=0.013$; Sidak post hoc analysis: control CTX $5 \mathrm{~h}$ vs control FC $5 \mathrm{~h}, p=0.034$ for c-Fos; $F_{(1,12)}=16.04 p=0.002$; Sidak post hoc analysis: control CTX $5 \mathrm{~h}$ vs control FC $5 \mathrm{~h}, p=0.0002$ for Npas4; $F_{(1,12)}=4.98 p=0.045$; Sidak post hoc analysis: control CTX 5 h vs control FC 5 h, $p=0.03$ for Cyr61, two-way ANOVA). This then led to a reduction in the second peak of IEG expression, with no effect on the first peak of IEG expression (Fig. $8 L-O ; F_{(1,12)}=5.39, p=0.038$; Sidak post hoc analysis: control CTX 5 h vs control FC $5 \mathrm{~h}, p=0.019$ for $\operatorname{Arc} ; F_{(1,12)}=6.21, p=$ 0.0004; Sidak post hoc analysis: control CTX $5 \mathrm{~h}$ vs control FC $5 \mathrm{~h}$, $p=0.0006$ for $c$-Fos; $F_{(1,12)}=14.67, p=0.002$; Sidak post hoc analysis: control CTX 5 h vs control FC $5 \mathrm{~h}, p=0.003$ for Npas4; $F_{(1,12)}=25.4, p=0.0003$; Sidak post hoc analysis: control CTX $5 \mathrm{~h}$ vs control FC 5 h, $p=0.0005$ for Cyr61, two-way ANOVA).

\section{Discussion}

In this study, we have made three important discoveries. First, we found that the expression of four plasticity-related IEGs peak twice in response to cued fear learning, with an increase in the presence of the DNA damage marker $\gamma \mathrm{H} 2 \mathrm{~A}$.X and the recruitment of Topo II $\beta$ to IEG promoters corresponding to the first peak of IEG expression, whereas an increase in DNA methylation and a time-dependent recruitment of Gadd $45 \gamma$ is associated with the second peak of IEG expression. Second, we have shown that inhibition of Topo II $\beta$ activity before the first peak of IEG expression impairs the consolidation of fear memory, as does the disruption of Gadd $45 \gamma$ binding before the second peak, strongly suggesting that these molecular events are both necessary for memory consolidation. Third, we have demonstrated that DsiRNA-mediated knockdown of a novel brain-enriched IEG, Cyr61, before the second peak of its expression impairs the consolidation of cued fear memory, a finding which extends the understanding of learning-induced IEGs in the PLPFC to include the epigenetic regulation of Cyr61 in the consolidation of associative fear memory.

Together, our results indicate that there is a tight temporal relationship between learning-induced DSBs, DNA repair, and DNA (de)methylation in the regulation of learning-induced IEG expression, and we highlight Gadd $45 \gamma$ as a central regulator of the temporal coding of IEG transcription that is required for fear memory consolidation. To our knowledge this is the first demonstration of a causal influence of Gadd $45 \gamma$ on the consolidation of cued fear memory, and the first model synthesizing the functional interaction of DSBs, DNA methylation, and DNA repairmediated DNA demethylation in a learning context. In addition, 


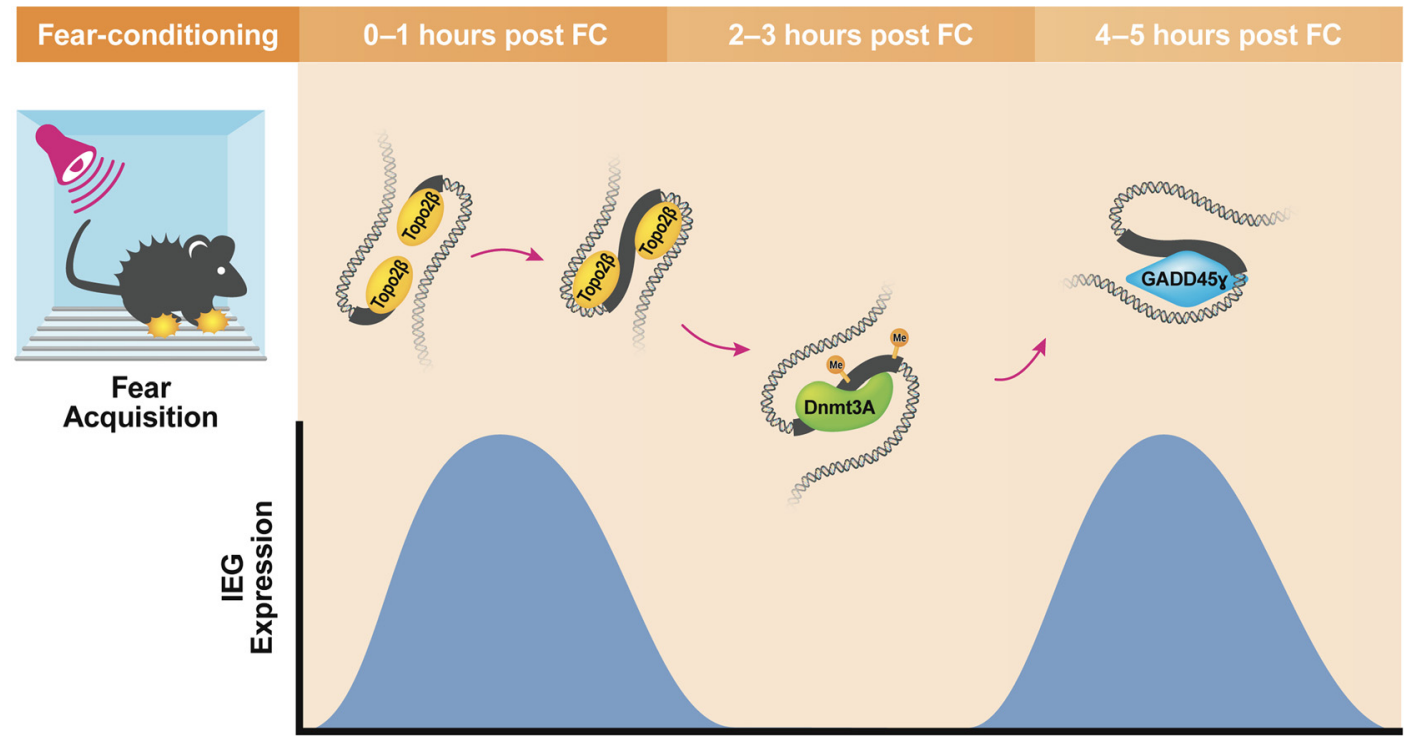

Figure 9. Fear learning leads to a rapid induction in IEG expression in the PLPFC that is mediated by Topo $2 \beta$ associated DSBs within their promoter region, and which is followed by an increase in DNMT3a-mediated DNA methylation at the same locus. The increased deposition of 5-mC results in the recruitment of the DNA repair associated protein Gadd $45 \gamma$, which is then necessary for the induction of a second peak of IEG expression and the consolidation of fear memory.

these data add mechanistically to the literature describing memory consolidation as a process which is not simply linear and proportional to the passage of time, but is instead continually and dynamically stabilized and destabilized across time.

Whereas previous studies observed that global Gadd $45 \beta$ knock-out affected contextual but not cued fear conditioning (Leach et al., 2012), we have found that Gadd45 $\gamma$, but not Gadd $45 \alpha$ or Gadd $45 \beta$, is required in the PLPFC for cued fear conditioning. This suggests that Gadd45 $\gamma$ may function in a region-specific, and thus task-specific, manner, an idea which is supported by the observation of Gadd $45 \gamma$ recruitment to the promoter of all of the IEGs at the same $5 \mathrm{~h}$ time point, with similarly reduced IEG mRNA expression at this time point following Gadd45 $\gamma$ knockdown. Selective temporal control over IEG expression is also supported by the observation that knockdown of Gadd $45 \gamma$, which binds to a variety of IEGs, impairs fear conditioning by a considerably larger margin than by knockdown of a single IEG, as in the case of Cyr61. We find this particularly interesting because it has been shown that Gadd $45 \beta$ binds more slowly to genes encoding neurotrophic factors (Ma et al., 2009). Thus, in addition to specificity for different brain regions and potential cell types, members of the Gadd45 family may also be targeting different classes of genes that have different temporal expression patterns.

Perhaps even more intriguing is the fact that all four IEGs we investigated are a hot spot for DNA breakage, and that this is related to dynamic DNA methylation states in all four cases. The time course analysis revealed that DSBs occur in the promoter regions of Arc, c-Fos, Npas4, and Cyr61 in response to fear learning, which is followed by a time-dependent increase in DNA methylation. Increased DNA methylation following DSBs has been suggested to occur in only a few cells after aberrant repair (Morano et al., 2014). Our data suggest that this phenomenon may be more widespread than previously thought, and in the brain may be used to control the rapid induction and temporal nature of learning-induced IEG expression (O'Hagan et al., 2008; Wossidlo et al., 2010; Morano et al., 2014). Furthermore, recent work has shown that both 5-formylcytosine, and 5-mC within CA dinucleotides, can epigenetically prime gene activity through- out the brain (Song et al., 2013; Stroud et al., 2017). In this study, we did not determine whether a reduction in 5-mC corresponding to the recruitment of Gadd $45 \gamma$ reflects removal of $5-\mathrm{mC}$ by DNA repair mechanisms, or further conversion of 5-mC to these downstream derivatives. Future studies will investigate whether Gadd $45 \gamma$ interacts with other factors to participate in the conversion of 5-mC to 5-formylcytosine, and whether there are metaplastic changes in IEG activation following the consolidation of fear memory. Whether DSBs and their recognition by Gadd $45 \gamma$ is required for the regulation of all IEGs that are induced by cued fear learning is not yet known. Furthermore, we did not identify any common motifs within the promoters of the four IEGs included in this investigation, which would have suggested a common target for the process of activity-induced DNA break and repair. Future studies will expand on this analysis to include a genome-wide profile of DSBs and Gadd45 $\gamma$ occupancy to determine whether this represents a general principle of temporal control over learning-induced gene expression, or if it is restricted to a subset of rapidly induced IEGs.

Gadd $45 \gamma$ is recruited to the promoter of each IEG only at the $5 \mathrm{~h}$ time point, which corresponds to the second wave of IEG expression. This observation is made more intriguing by the long-held position that there are two time periods during which protein synthesis inhibitors impair consolidation, with observations of these two critical windows being immediately following learning and 3-6 h later (Grecksch and Matthies, 1980; Freeman et al., 1995; Chew et al., 1996). The dual observation that these genes are subject to both DSBs and the later recruitment of Gadd $45 \gamma$ is not to be ignored as it suggests a two-tier process whereby DSBs are needed to activate IEGs at the first time point, and activity-dependent DNA demethylation and repair guided by Gadd $45 \gamma$ is critical for this pattern of IEG expression to trigger processes required for long-term memory. As described by Igaz et al. (2002), two peaks of learning-induced gene expression fit within the lingering consolidation hypothesis, which states that there are processes which occur across time and result in continued destabilization and re-stabilization of memory traces, contrasted to the simpler model describing a linear relationship between memory strength and time (Dudai and Eisenberg, 
2004). This distinction is theoretically important as the latter assumes certain time periods, such as $24 \mathrm{~h}$ post-learning, could be used as a control where manipulations should have no effect. In fact, Katche et al. (2010) have shown that the manipulation of c-Fos $24 \mathrm{~h}$ after initial training impairs long-term memory storage. Here, we add mechanistically to this model by demonstrating that a DNA modification switch, which is activated by DSBs and regulated by DNA demethylation and repair, is intimately involved in this process; we also extend these findings to include the neural plasticity-related IEGs Arc, c-Fos, Npas4, and Cyr61.

The model would make further predictions that DNA methylation and repair may not only be critical for the initial learninginduced induction and encoding of information at the level of gene expression, but also indicate a retrieval-induced recapitulation of transcriptional activity. Supporting this idea is the recent observation that retrieval-induced Tet 3 gene expression is necessary for retrieval and reconsolidation (Liu et al., 2018), as well as selective retrieval impairment by infusion of DNA methyltransferase inhibitors into the PLPFC (Han et al., 2010), although further work is required to establish this. It also remains to be determined whether the phenomenon of DSB followed by DNA methylation and the recruitment of Gadd $45 \gamma$ generalizes to other classes of genes, or whether other mechanisms of DNA modification also follow this time course. Regardless of these open questions, our data imply a two-hit model of IEG expression whereby the initial induction is dependent on learning-induced DSBs and increased DNA methylation, and the second wave depends on Gadd45 $\gamma$-mediated DNA demethylation and repair (Fig. 9), both of which represent critical aspects of the memory consolidation process.

\section{References}

Albrecht C, von der Kammer H, Mayhaus M, Klaudiny J, Schweizer M, Nitsch RM (2000) Muscarinic acetylcholine receptors induce the expression of the immediate early growth regulatory gene CYR61. J Biol Chem 275: 28929-28936. CrossRef Medline

Baker-Andresen D, Ratnu VS, Bredy TW (2013) Dynamic DNA methylation: a prime candidate for genomic metaplasticity and behavioral adaptation. Trends Neurosci 36:3-13. CrossRef Medline

Barreto G, Schäfer A, Marhold J, Stach D, Swaminathan SK, Handa V, Döderlein G, Maltry N, Wu W, Lyko F, Niehrs C (2007) Gadd45a promotes epigenetic gene activation by repair-mediated DNA demethylation. Nature 445:671-675. CrossRef Medline

Befort K, Karchewski L, Lanoue C, Woolf CJ (2003) Selective up-regulation of the growth arrest DNA damage-inducible gene Gadd45 alpha in sensory and motor neurons after peripheral nerve injury. Eur J Neurosci 18:911-922. CrossRef Medline

Calderwood SK (2016) A critical role for topoisomerase IIb and DNA double strand breaks in transcription. Transcription 7:75-83. CrossRef Medline

Chew SJ, Vicario DS, Nottebohm F (1996) Quantal duration of auditory memories. Science 274:1909-1914. CrossRef Medline

Day JJ, Sweatt JD (2010) DNA methylation and memory formation. Nat Neurosci 13:1319-1323. CrossRef Medline

Dejean C, Courtin J, Karalis N, Chaudun F, Wurtz H, Bienvenu TC, Herry C (2016) Prefrontal neuronal assemblies temporally control fear behaviour. Nature 535:420-424. CrossRef Medline

Dudai Y, Eisenberg M (2004) Rites of passage of the engram: reconsolidation and the lingering consolidation hypothesis. Neuron 44:93-100. CrossRef Medline

Freeman FM, Rose SP, Scholey AB (1995) Two time windows of anisomycin-induced amnesia for passive avoidance training in the dayold chick. Neurobiol Learn Mem 63:291-295. CrossRef Medline

Gallo FT, Katche C, Morici JF, Medina JH, Weisstaub NV (2018) Immediate early genes, memory and psychiatric disorders: focus on c-fos, Egrl and arc. Front Behav Neurosci 12:79. CrossRef Medline

Giustino TF, Maren S (2015) The role of the medial prefrontal cortex in the conditioning and extinction of fear. Front Behav Neurosci 9:298. CrossRef Medline

Grassi D, Franz H, Vezzali R, Bovio P, Heidrich S, Dehghanian F, Lagunas N, Belzung C, Krieglstein K, Vogel T (2017) Neuronal activity, TGF $\beta$ signaling and unpredictable chronic stress modulate transcription of Gadd45 family members and DNA methylation in the hippocampus. Cereb Cortex 27:4166-4181. CrossRef Medline

Grecksch G, Matthies H (1980) Two sensitive periods for the amnesic effect of anisomycin. Pharmacol Biochem Behav 12:663-665. CrossRef Medline

Han J, Li Y, Wang D, Wei C, Yang X, Sui N (2010) Effect of 5-aza-2deoxycytidine microinjecting into hippocampus and prelimbic cortex on acquisition and retrieval of cocaine-induced place preference in C57BL/6 mice. Eur J Pharmacol 642:93-98. CrossRef Medline

Igaz LM, Vianna MR, Medina JH, Izquierdo I (2002) Two time periods of hippocampal mRNA synthesis are required for memory consolidation of fear-motivated learning. J Neurosci 22:6781-6789. CrossRef Medline

Izquierdo I, McGaugh JL (2000) Behavioural pharmacology and its contribution to the molecular basis of memory consolidation. Behav Pharmacol 11:517-534. CrossRef Medline

Jarome TJ, Butler AA, Nichols JN, Pacheco NL, Lubin FD (2015) NF- $\kappa$ B mediates Gadd $45 \beta$ expression and DNA demethylation in the hippocampus during fear memory formation. Front Mol Neurosci 8:54. CrossRef Medline

Kaas GA, Zhong C, Eason DE, Ross DL, Vachhani RV, Ming GL, King JR, Song H, Sweatt JD (2013) TET1 controls CNS 5-methylcytosine hydroxylation, active DNA demethylation, gene transcription, and memory formation. Neuron 79:1086-1093. CrossRef Medline

Kandel ER (2001) The molecular biology of memory storage: a dialogue between genes and synapses. Science 294:1030-1038. CrossRef Medline

Katche C, Bekinschtein P, Slipczuk L, Goldin A, Izquierdo IA, Cammarota M, Medina JH (2010) Delayed wave of c-Fos expression in the dorsal hippocampus involved specifically in persistence of long-term memory storage. Proc Natl Acad Sci U S A 107:349-354. CrossRef Medline

Klavir O, Prigge M, Sarel A, Paz R, Yizhar O (2017) Manipulating fear associations via optogenetic modulation of amygdala inputs to prefrontal cortex. Nat Neurosci 20:836-844. CrossRef Medline

Kuo LJ, Yang LX (2008) Gamma-H2AX: a novel biomarker for DNA double-strand breaks. In Vivo 22:305-309. Medline

Leach PT, Poplawski SG, Kenney JW, Hoffman B, Liebermann DA, Abel T, Gould TJ (2012) Gadd45b knockout mice exhibit selective deficits in hippocampus-dependent long-term memory. Learn Mem 19:319-324. CrossRef Medline

Lefer D, Perisse E, Hourcade B, Sandoz J, Devaud JM (2012) Two waves of transcription are required for long-term memory in the honeybee. Learn Mem 20:29-33. CrossRef Medline

Li X, Wei W, Ratnu VS, Bredy TW (2013) On the potential role of active DNA demethylation in establishing epigenetic states associated with neural plasticity and memory. Neurobiol Learn Mem 105:125-132. CrossRef Medline

Li X, Wei W, Zhao QY, Widagdo J, Baker-Andresen D, Flavell CR, D’Alessio A, Zhang Y, Bredy TW (2014) Neocortical Tet3-mediated accumulation of 5-hydroxymethylcytosine promotes rapid behavioral adaptation. Proc Natl Acad Sci U S A 111:7120-7125. CrossRef Medline

Lin Q, Wei W, Coelho CM, Li X, Baker-Andresen D, Dudley K, Ratnu VS, Boskovic Z, Kobor MS, Sun YE, Bredy TW (2011) The brain-specific microRNA miR-128b regulates the formation of fear-extinction memory. Nat Neurosci 14:1115-1117. CrossRef Medline

Liu C, Sun X, Wang Z, Le Q, Liu P, Jiang C, Wang F, Ma L (2018) Retrievalinduced upregulation of Tet3 in pyramidal neurons of the dorsal hippocampus mediates cocaine-associated memory reconsolidation. Int J Neuropsychopharmacol 21:255-266. CrossRef Medline

Ma DK, Guo JU, Ming GL, Song H (2009) DNA excision repair proteins and Gadd45 as molecular players for active DNA demethylation. Cell Cycle 8:1526-1531. CrossRef Medline

Madabhushi R, Gao F, Pfenning AR, Pan L, Yamakawa S, Seo J, Rueda R, Phan TX, Yamakawa H, Pao PC, Stott RT, Gjoneska E, Nott A, Cho S, Kellis M, Tsai LH (2015) Activity-induced DNA breaks govern the expression of neuronal early-response genes. Cell 161:1592-1605. CrossRef Medline

Massart R, Barnea R, Dikshtein Y, Suderman M, Meir O, Hallett M, Kennedy P, Nestler EJ, Szyf M, Yadid G (2015) Role of DNA methylation in the 
nucleus accumbens in incubation of cocaine craving. J Neurosci 35:80428058. CrossRef Medline

Minatohara K, Akiyoshi M, Okuno H (2016) Role of immediate-early genes in synaptic plasticity and neuronal ensembles underlying the memory trace. Front Mol Neurosci 8:78. CrossRef Medline

Morano A, Angrisano T, Russo G, Landi R, Pezone A, Bartollino S, Zuchegna C, Babbio F, Bonapace IM, Allen B, Muller MT, Chiariotti L, Gottesman ME, Porcellini A, Avvedimento EV (2014) Targeted DNA methylation by homology-directed repair in mammalian cells. transcription reshapes methylation on the repaired gene. Nucleic Acids Res 42:804-821. CrossRef Medline

Nainar S, Marshall PR, Tyler CR, Spitale RC, Bredy TW (2016) Evolving insights into RNA modifications and their functional diversity in the brain. Nat Neurosci 19:1292-1298. CrossRef Medline

Niehrs C, Schäfer A (2012) Active DNA demethylation by Gadd45 and DNA repair. Trends Cell Biol 22:220-227. CrossRef Medline

O'Hagan HM, Mohammad HP, Baylin SB (2008) Double strand breaks can initiate gene silencing and SIRT1-dependent onset of DNA methylation in an exogenous promoter CpG island. PLoS Genetics 4:e1000155. CrossRef Medline

Pastink A, Eeken JC, Lohman PH (2001) Genomic integrity and the repair of double-strand DNA breaks. Mutat Res 480-481:37-50. CrossRef Medline

Ploski JE, Pierre VJ, Smucny J, Park K, Monsey MS, Overeem KA, Schafe GE (2008) The activity-regulated cytoskeletal-associated protein (Arc/ Arg3.1) is required for memory consolidation of Pavlovian fear conditioning in the lateral amygdala. J Neurosci 28:12383-12395. CrossRef Medline

Ploski JE, Monsey MS, Nguyen T, DiLeone RJ, Schafe GE (2011) The neuronal PAS domain protein 4 (Npas4) is required for new and reactivated fear memories. PloS One 6:e23760. CrossRef Medline

Rai K, Huggins IJ, James SR, Karpf AR, Jones DA, Cairns BR (2008) DNA demethylation in zebrafish involves the coupling of a deaminase, a glycosylase, and Gadd45. Cell 135:1201-1212. CrossRef Medline

Ratnu VS, Wei W, Bredy TW (2014) Activation-induced cytidine deaminase regulates activity-dependent BDNF expression in post-mitotic cortical neurons. Eur J Neurosci 40:3032-3039. CrossRef Medline

Rizzo V, Touzani K, Raveendra BL, Swarnkar S, Lora J, Kadakkuzha BM, Liu XA, Zhang C, Betel D, Stackman RW, Puthanveettil SV (2017) Encoding of contextual fear memory requires de novo proteins in the prelimbic cortex. Biol Psychiatry Cogn Neurosci Neuroimaging 2:158-169. CrossRef Medline

Rudenko A, Dawlaty MM, Seo J, Cheng AW, Meng J, Le T, Faull KF, Jaenisch R, Tsai LH (2013) Tet1 is critical for neuronal activity-regulated gene expression and memory extinction. Neuron 79:1109-1122. CrossRef Medline

Sakuma K, Komatsu H, Maruyama M, Imaichi S, Habata Y, Mori M (2015) Temporal and spatial transcriptional fingerprints by antipsychotic or pro- psychotic drugs in mouse brain. PLoS One 10:e0118510. CrossRef Medline

Santos TB, Kramer-Soares JC, Favaro VM, Oliveira MGM (2017) Involvement of the prelimbic cortex in contextual fear conditioning with temporal and spatial discontinuity. Neurobiol Learn Mem 144:1-10. CrossRef Medline

Savell KE, Gallus NVN, Simon R, Brown J, Revanna JS, Osborn MK, Song EY, O’Malley JJ, Stackhouse CT, Norvil A, Gowher H, Sweatt JD, Day JJ (2016) Extra-coding RNAs regulate neuronal DNA methylation dynamics. Nat Comm 7:12091. CrossRef Medline

Smith IF, Shuai J, Parker I (2011) Active generation and propagation of $\mathrm{Ca}^{2+}$ signals within tunneling membrane nanotubes. Biophys J 100:L37L39. CrossRef Medline

Song CX, Szulwach KE, Dai Q, Fu Y, Mao SQ, Lin L, Street C, Li Y, Poidevin M, Wu H, Gao J, Liu P, Li L, Xu GL, Jin P, He C (2013) Genome-wide profiling of 5-formylcytosine reveals its roles in epigenetic priming. Cell 153:678-691. CrossRef Medline

Stroud H, Su SC, Hrvatin S, Greben AW, Renthal W, Boxer LD, Nagy MA, Hochbaum DR, Kinde B, Gabel HW, Greenberg ME (2017) Early-life gene expression in neurons modulates lasting epigenetic states. Cell 171: 1151-1164.e16. CrossRef Medline

Su Y, Ming GL, Song H (2015) DNA damage and repair regulate neuronal gene expression. Cell Res 25:993-994. CrossRef Medline

Sultan FA, Wang J, Tront J, Liebermann DA, Sweatt JD (2012) Genetic deletion of gadd $45 \mathrm{~b}$, a regulator of active DNA demethylation, enhances long-term memory and synaptic plasticity. J Neurosci 32:17059-17066. CrossRef Medline

Sun X, Lin Y (2016) Npas4: linking neuronal activity to memory. Trends Neurosci 39:264-275. CrossRef Medline

Tischmeyer W, Grimm R (1999) Activation of immediate early genes and memory formation. Cell Mol Life Sci 55:564-574. CrossRef Medline

Widagdo J, Zhao QY, Kempen MJ, Tan MC, Ratnu VS, Wei W, Leighton L, Spadaro PA, Edson J, Anggono V, Bredy TW (2016) Experiencedependent accumulation of N6-methyladenosine in the prefrontal cortex is associated with memory processes in mice. J Neurosci 36:6771-6777. CrossRef Medline

Wossidlo M, Arand J, Sebastiano V, Lepikhov K, Boiani M, Reinhardt R,Schöler H, Walter J (2010) Dynamic link of DNA demethylation, DNA strand breaks and repair in mouse zygotes. EMBO J 29:1877-1888. CrossRef Medline

Wright KN, Hollis F, Duclot F, Dossat AM, Strong CE, Francis TC, Mercer R, Feng J, Dietz DM, Lobo MK, Nestler EJ, Kabbaj M (2015) Methyl supplementation attenuates cocaine-seeking behaviors and cocaine-induced c-Fos activation in a DNA methylation-dependent manner. J Neurosci 35:8948-8958. CrossRef Medline

Xiao G, Chicas A, Olivier M, Taya Y, Tyagi S, Kramer FR, Bargonetti J (2000) A DNA damage signal is required for p53 to activate gadd45. Cancer Res 60:1711-1719. Medline 